https://doi.org/10.11646/zootaxa.4358.3.1

http://zoobank.org/urn:lsid:zoobank.org:pub:25796F05-AAAB-4D1E-B09E-9138635F1D56

\title{
New genera, species and records of Afrotropical Phaneropterinae (Orthoptera, Tettigoniidae) preserved at the Royal Belgian Institute of Natural Sciences, Bruxelles
}

\author{
BRUNO MASSA \\ Department of Agriculture, Food and Forest Sciences, University of Palermo, Viale Scienze Bd 5a, 90128 Palermo, Italy. \\ E-mail: bruno.massa@unipa.it
}

\begin{abstract}
The results of the study of the rich material of Orthoptera Phaneropterinae at the Royal Belgian Institute of Natural Sciences, Bruxelles, are reported. The following new taxa are described: Dithela longicaudata $\mathbf{n}$. sp. from the Democratic Republic of Congo, Terpnistriella bredoi n. gen. n. sp. from the Democratic Republic of Congo, Mimoscudderia paulyi n. sp. from the Madagascar, Pseudogoetia constanti n. gen. n. sp. from the Democratic Republic of Congo (including a table listing differences with related genera), and Materuana abyssinica n. sp. from the Ethiopia. Some taxonomic and distributional data about the following species are also reported: Melidia claudiae Massa, 2015, Symmetrokarschia africana (Brunner von Wattenwyl, 1878), Eurycorypha ndokiensis Massa, 2016, Eurycorypha prasinata Stål, 1874, Eurycorypha spinulosa Karsch, 1889, two unidentified species of Eurycorypha recorded by Griffini in 1908, Tylopsis irregularis Karsch, 1893, Pardalota asymmetrica Karsch, 1896, Pardalota haasi Griffini, 1908, Pardalota karschiana Enderlein, 1907, Pardalota versicolor Brunner von Wattenwyl, 1878, Poecilogramma cloetensi (Griffini, 1908), Poecilogramma annulifemur Karsch, 1887, Morgenia spathulifera Griffini, 1908, Mimoscudderia picta Carl, 1914 and Angustithorax spiniger Massa, 2015. The following synonymy is established: Plangiopsis shoutedeni Griffini, 1908 = Plangiopsis adeps Karsch, 1896; the latter species, recently moved to the genus Plangiola Bolívar, 1906 is again transferred to the original genus.
\end{abstract}

Key words: Taxonomy, new genera, new species, tropical Africa

\section{Introduction}

During a two week visit in April-May 2017 to the Royal Belgian Institute of Natural Sciences, Bruxelles, within a Synthesys Project (European Community Research Infrastructure Action under the FP7 “Capacities” Programme), I had the opportunity to study and select many specimens of Orthoptera Tettigoniidae, that resulted particularly interesting. Some of them belong to unknown taxa or to known taxa, of which scattered or very few data were previously reported. On the whole, five new taxa (two new genera and species, and three new species) are here listed and new taxonomical or distributional data of other 17 species are reported.

\section{Material and methods}

Specimens were photographed with a Nikon Coolpix 4500 digital camera, mounted on a Wild M5 or a Leica Stereomicroscope, and photos were integrated using the freeware CombineZP (Hadley 2008). Mounted specimens were measured with a digital caliper (precision $0.01 \mathrm{~mm}$ ); the following measurements were taken (all in mm): Body length: dorsal length from the head to the apex of the abdomen, ovipositor excluded in females; Pronotum length: length of the pronotum along dorsal median line; Pronotum height: maximum height of pronotum; Hind femur: length of hind femur; Hind tibia: maximum length of hind tibia; Tegmina: length and maximum width of tegmina; Ovipositor: maximum length; the curvature of the ovipositor is not considered, the measurements were taken from the subgenital plate to the tip of the ovipositor. 
Abbreviations:

$\mathrm{BMCP}=$ Bruno Massa Collection, Palermo

$\mathrm{MfN}=$ Museum für Naturkunde, Berlin

MNCN = Museo Nacional de Ciencias Naturales, Madrid

MRT $=$ Museo Regionale di Storia Naturale, Terrasini (Palermo)

NHMP $=$ National Museum Natural History, Prague

NMW $=$ Naturhistorisches Museum, Vienna

RBINS $=$ Royal Belgian Institute of Natural Sciences, Bruxelles

\section{Results}

\section{Tribe Phaneropterini Burmeister, 1838}

\section{Genus Melidia Stål, 1876}

Remarks. Stål (1876) described the genus Melidia, highlighting the following main differences with Phaneroptera Serville, 1831: fastigium of vertex more concave, wings longer and wider, apex of radial area of tegmina larger, humeral sinus less deep, sub-rectangular, lower and posterior margins of pronotum lobes rounded. Ragge (1980) also highlighted some differences with Phaneroptera, as the more robust body, the relatively broader fore wings (less than 5 times longer that their maximum width) and in the males the stridulatory area of the left tegmen brown or conspicuously marked with brown, thus contrasting with the general green colouring. Concerning the ratio length/width of tegmina, Melidia claudiae has tegmina more than 5 times longer than their maximum length, but other characters lie within the genus Melidia.

\section{Melidia claudiae Massa, 2015}

Figs $1 \mathrm{~A}-1 \mathrm{C}$

Massa, 2015. Zookeys, 472: 87.

Material examined. Democratic Republic of Congo, Katofio V.1939, H.J. Brédo (50^, 1 \%) (RBINS).

Measurements. Males. Body length: 13.5-15.0; length of pronotum: 3.4-3.6; height of pronotum: 3.0-3.2; length hind femur: 17.0-18.6; length of hind tibia: 18.5-21.3; length of tegmina: 23.9-25.5; width of tegmina: 4.75.3. Female. Body length: 11.8; length of pronotum: 3.0; height of pronotum: 2.4; length hind femur: 17.0; length of hind tibia: 19.0; length of tegmina: 19.9; width of tegmina: 3.5 .

Remarks. The description of this species was based on 2 males (Massa 2015); the series listed above contains also one female, other than 5 males. M. claudiae is characterized by narrower tegmina than congeneric species (see Massa 2015 and measurements). The stridulatory area is presented in Fig. 1A, the stridulatory file (previously undescribed) consists of 18 teeth, of which 5 proximal larger and 13 distal smaller (Fig. 1B).

Characters of the female. Similar as male. Colour. Yellow-green. The ovipositor is gently up-curved and has two lateral bulges at its base, the subgenital plate is short and pointed (Fig. 1C).

\section{Genus Dithela Karsch, 1890}

Remarks. The genus Dithela is characterized by small dorsolateral tubercle on each side of the pronotum, fore coxae without spine, fore femora armed, fore and mid tibiae without dorsal spurs, radial area with series of callosities on principal cross-veins, hind margin of male left tegmen markedly excavate just beyond stridulatory region, subgenital plate without styli. The species below described, Dithela longicaudata $\mathbf{n}$. sp., does not show the callosities on the tegmina, has 1 spur on dorsal fore tibiae, 2 spurs on dorsal mid tibiae, and has tegmina clearly shorter than hind wings, different from the two known species of the genus, D. rectiloba Karsch, 1890 and $D$. acuticercus Sjöstedt, 1912. However, it is tentatively ascribed to the genus Dithela, based on the other characters. 


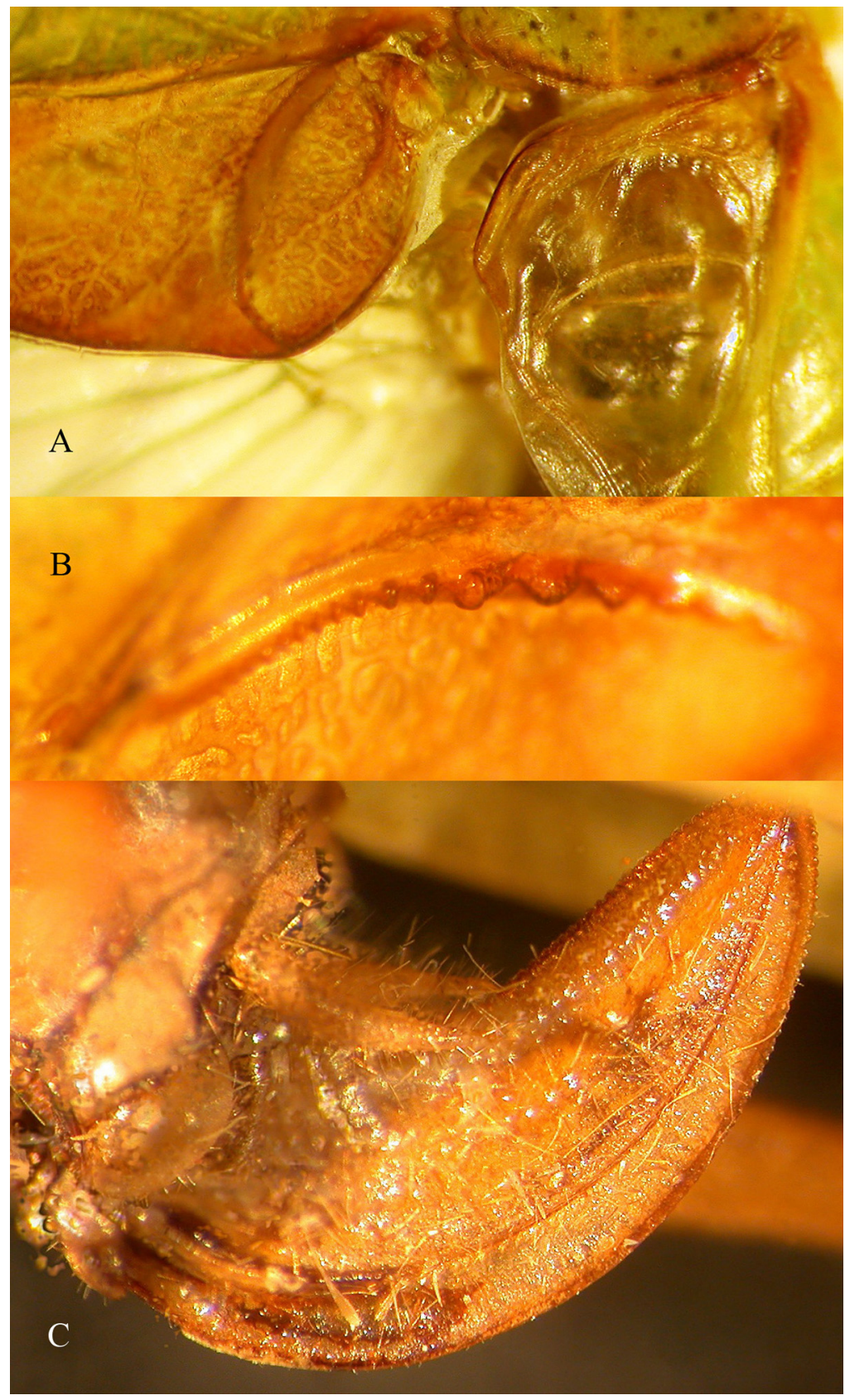

FIGURE 1. Melidia claudiae Massa, 2015. A) Stridulatory area of left and right tegmina of male. B) Stridulatory file under the left tegmen of male. C) Female ovipositor.

\section{Dithela longicaudata $\mathrm{n}$. sp.}

Figs $2 \mathrm{~A}-2 \mathrm{H}$

Material examined and depository. Democratic Republic of Congo, Kalulu 6.V.1939, H.J. Brédo ( $\delta$ holotype, $1 \delta$ paratype, without hind legs) (RBINS).

Other material examined. Dithela rectiloba Karsch, 1890. Cameroon, Barombi Station, Preuss ( $\delta$ holotype) $(\mathrm{MfN})$; Equatorial Guinea, Fernando Poo $(1 \hat{\jmath}, 1 \uparrow)(\mathrm{MNCN})$; Dithela acuticercus Sjöstedt, 1912. Cameroon, Victoria $\left(1{ }^{\Uparrow}\right)(\mathrm{MfN})$.

Measurements. Males. Body length: 15.2-15.7; length of pronotum: 2.7-2.9; height of pronotum: 2.1-2.3; length hind femur: 19.2; length of hind tibia: 20.0; length of tegmina: 19.7-21.0; width of tegmina: 3.7-4.2. 

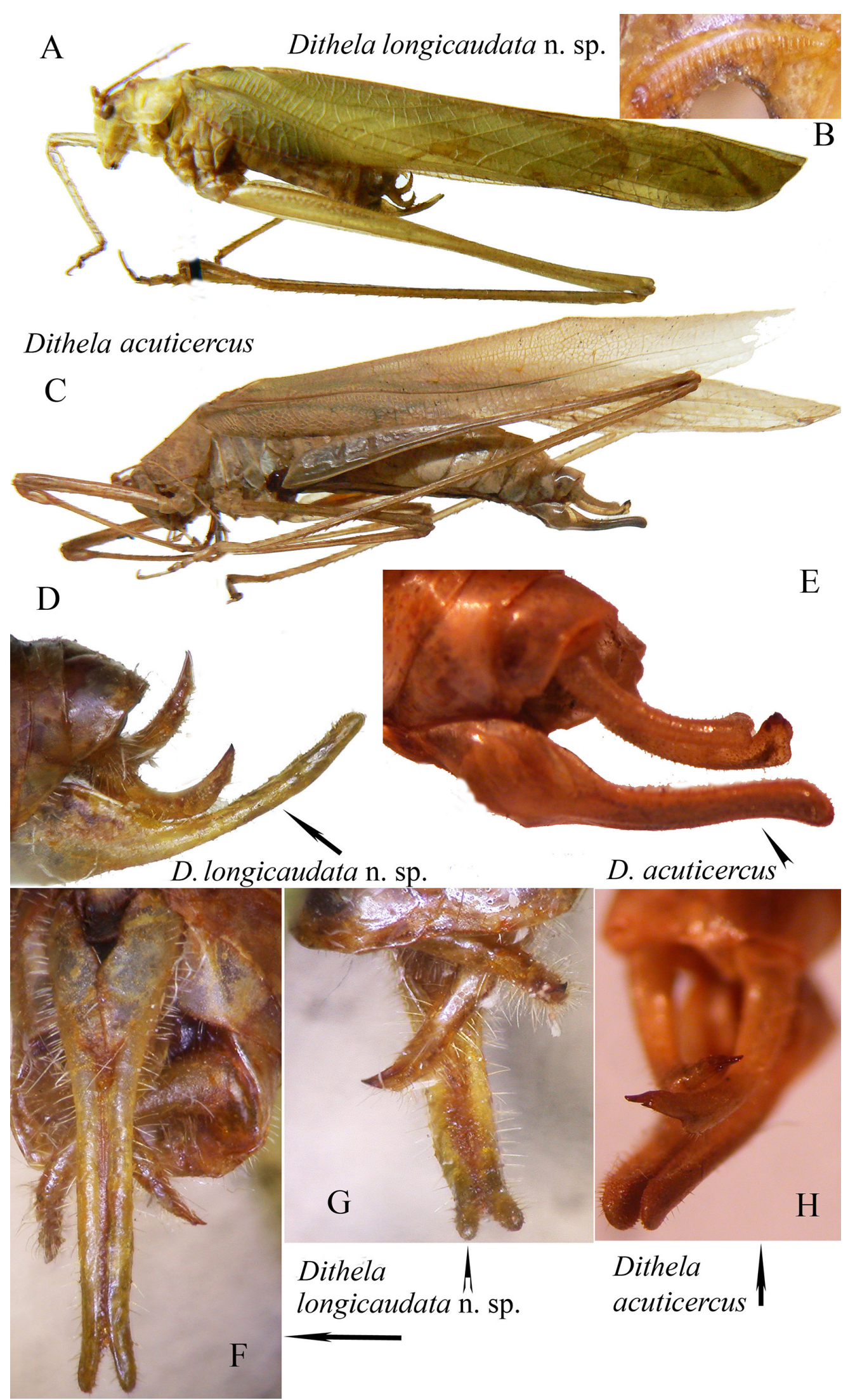

Dithela
acuticercus

FIGURE 2. Dithela longicaudata $\mathbf{n}$. sp. and Dithela acuticercus Sjöstedt, 1912. A) Lateral view of D. longicaudata $\mathbf{n}$. sp. B) Stridulatory file of D. longicaudata $\mathbf{n}$. sp. C) Lateral view of D. acuticercus. D) Lateral view of last abdominal segments and cerci of $D$. longicaudata $\mathbf{n}$. sp. E) Lateral view of last abdominal segments and cerci of $D$. acuticercus. F) ventral view of the subgenital plate of D. longicaudata n. sp. G) Dorsal view of cerci and subgenital plate of D. longicaudata n. sp. H) Dorsal view of cerci and subgenital plate of $D$. acuticercus. 
Diagnosis. It is an atypical Dithela, characterized by the presence of 1 spur on the dorsal fore tibiae, 2 spurs on dorsal mid tibiae, tegmina clearly shorter than hind wings, cerci pointed and up-curved, subgenital plate long, narrow with two parallel lobes, apically divergent.

Description of the male (Fig. 2A). Colour. Green with yellowish-green legs, antennae brown, stridulatory area of the left tegmen a little darkened. Head. Fastigium of vertex very narrow, sulcate above, separated from the fastigium of frons, which is tuberculated. Eyes rounded, well projecting, 2 times as smaller than subocular groove. Pronotum. Lobes very low and humeral sinus barely marked, anterior margin of pronotum straight, posterior rounded. Legs. Fore coxae unarmed. Fore tibiae furrowed superiorly, distinctly widening above tympanum. Tympanum open on inner and outer sides. Fore femora armed with 4-7 spines on ventral inner and 3-6 on ventral outer margins, fore tibiae with 6 spines +1 spur on ventral inner and outer margins, and 2 spines +1 spur on dorsal outer margin. Mid femora with 6-9 spines on ventral outer margin, mid tibiae with 8 spines +1 spur on ventral inner and outer margins and 5-6 spines +1 spur on dorsal inner and outer margins. Hind femora unarmed, hind tibiae with 5-6 spines on ventral inner margin and ca. 40 spines on dorsal inner and outer margins +3 spurs on each side. Wings. Tegmina narrow. Stridulatory area of the left tegmen stout and long, mirror of the right tegmen wide. Stridulatory file short, ca. $1.2 \mathrm{~mm}$ long, consisting of less than 40 unevenly distributed teeth (Fig. 2B). Abdomen. $10^{\text {th }}$ tergite unmodified, with a straight hind margin. Cerci long, pointed and up-curved (Fig. 2D), shorter than the subgenital plate. Subgenital plate long and narrow with two parallel lobes, apically divergent, styli absent (Figs 2F, $2 \mathrm{G})$.

Female: unknown.

Affinities. D. longicaudata n. sp. differs clearly from the two known species of Dithela by the characters reported in the discussion of the genus. Only D. acuticercus (Fig. 2C) is vaguely similar to D. longicaudata n. sp., but it differs by the shape of wings and of the subgenital plate and cerci (Figs 2E, 2H).

Etymology. From Latin = with long tail.

Distribution. Actually known only from the Democratic Republic of Congo.

\section{Symmetrokarschia africana (Brunner von Wattenwyl, 1878)}

Symmetropleura africana Brunner von Wattenwyl, 1878. Monographie der Phaneropteriden, 246.

Material examined. Democratic Republic of Congo ( $\widehat{c}$ holotype) (NMV); Democratic Republic of Congo,

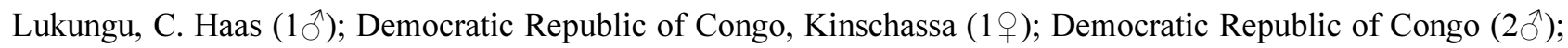

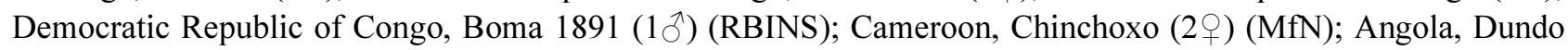
$\left(1 \jmath^{\lambda}\right)(\mathrm{MCNM})$.

Remarks. The subgenital plate, not well presented by Massa (2015), is reported in Figs 3A and 3B. This species is known from Democratic Republic of Congo (type locality), Cameroon and Angola (Massa 2015).

\section{Tribe Amblycoryphini Brunner von Wattenwyl, 1878}

\section{Eurycorypha aequatorialis Krauss, 1890?}

Krauss, 1890. Zoologische Jahrbücher. Abt. Syst. Geogr. und Biol. der Tiere, 5 (4): 663.

Material examined. Democratic Republic of Congo, Ngowa 16.XI.1938, R.P.J. Mertens (1 $\overbrace{}^{\Uparrow})$; Democratic Republic of Congo, Mission De Saeger 11.I.1950 (1ð) (RBINS).

Remarks. The last tergite of this taxon is similar to the specimen described by Giglio-Tos (1907) as the male of $E$. aequatorialis Krauss, 1890. Concerning the latter and the difficulty in the genus Eurycorypha to match male and female of the same species, it seems inappropriate that the male of E. aequatoralis was described from Madimba (Democratic Republic of Congo), while the female holotype came from Rolas Is. (Sao Tomé, Equatorial Guinea). Thus, it is yet uncertain that the male described by Giglio-Tos (1907) does actually belong to $E$. aequatorialis or to as yet undescribed species. 


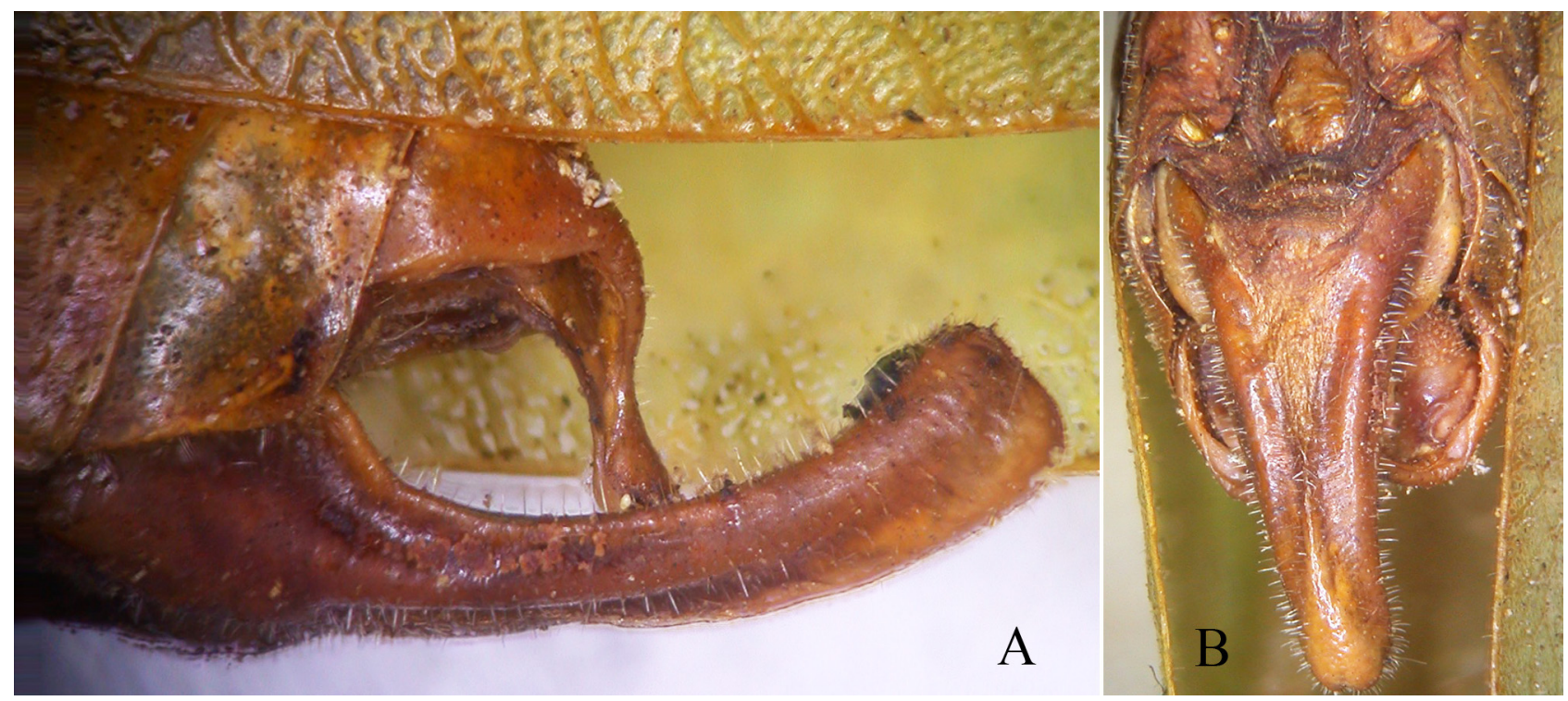

FIGURE 3. Symmetrokarschia africana (Brunner von Wattenwyl, 1878). A) Lateral view of last abdominal segments. B) Ventral view of the subgenital plate.

\section{Eurycorypha ndokiensis Massa, 2016}

Massa, 2016. Entomologia 4 (303): 4.

Material examined. Angola, Kabinda (1 $\left.\delta^{\Uparrow}\right)$ (RBINS).

Remarks. Previously known only from Central African Republic (Massa 2016).

\section{Eurycorypha prasinata Stål 1874}

Material examined. Madagascar, Morarano-Chrome forest (1 $\delta_{\text {); }}$ Madagascar, $25 \mathrm{~km}$ West Marontsetra 13.IV.1991, A. Pauly (1ठ̋); Madagascar, Foulpointe I.1994, A. Pauly (1ㅇ) (RBINS); Madagascar, Antalaba (1ㅇ) (NHMP).

Measurements. Males. Body length: 11.3-12.0; length of pronotum: 3.4-3.5; height of pronotum: 2.9-3.0; length hind femur: 11.1-12.1; length of hind tibia: 11.9-12.3; length of tegmina: 21.0-22.0; width of tegmina: 4.95.1. Female. Body length: 14.8-15.2; length of pronotum: 3.8-4.2; height of pronotum: 3.9-4.0; length hind femur: 13.9-14.1; length of hind tibia: 15.0-15.8; length of tegmina: 24.5-26.7; width of tegmina: 6.0-8.4.

Remarks. Only the female of this species was known (Stål 1874), characterized by the pronotum with rough punctuation. Karsch (1889) reported it from some continental African countries; however, it is supposed to be an endemic taxon from Madagascar and the description of the male has to be carried out from Madagascar material. The specimens above listed (both males and females) have rough punctuation on the pronotum and small black dots scattered on the tegmina and may be considered to belong to the same species, E. prasinata. It is possible to exclude E. brevipennis Karsch, 1889 from Madagascar, that also has a wrinkled pronotum with definite margins, but its tegmina are rather short and very oval, with the hind wings no longer than fore wings.

Characters of male. Anterior margin of pronotum concave, posterior margin rounded. 5 spines on inner margin of fore femora, 5 spines on inner ventral margin of fore tibiae, mid femora unarmed, mid tibiae with 7 spines on inner and outer ventral margins, hind femora with 8 spines on outer and 3 on inner ventral margins, hind tibia with 3 apical spurs on each side. Last tergite not modified, cerci incurved, stout with a black tip. Subgenital plate concave with very small styli.

Distribution. Madagascar and Comoro Is. (Chopard 1958); the presence in continental Africa has to be confirmed. 


\section{Eurycorypha spinulosa Karsch, 1889}

Figs $4 \mathrm{~A}-4 \mathrm{D}$

Karsch, 1889 (1888). Berlin Ent. Z. 32: 455.

Material examined. Cameroon, Mukonje Farm, R. Rohde (2へ, $3 \uparrow)$; Cameroon, Mt. Koupé 31.I-8.II.1983, J. van

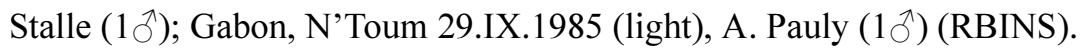

Measurements. Males. Body length: 18.0-18.5; length of pronotum: 4.0-4.1; height of pronotum: 3.6-3.8; length hind femur: 11.8-12.1; length of hind tibia: 13.5-14.0; length of tegmina: 22.5-23.0; width of tegmina: 7.07.4 .

Characters of the male. The description of the male by Karsch (1891) is too short, further characters are below reported. Small species, fastigium of vertex wide, ca. 2 times as wide as scapus. Fronto-genal carinae welldeveloped. Antennae as long as body. Pronotum flat, with slightly concave anterior margin and rounded posterior margin. Lateral carinae distinct, humeral excision well-developed, integuments smooth. Tegmina about 3.0 times longer than broad, rounded at the tip; differently from most species of the genus Eurycorypha, second pairs of wings are nearly as long as tegmina. Stridulatory file $1.2 \mathrm{~mm}$ long, curved, with ca. 80 evenly spaced teeth, central higher than lateral ones (Fig. 4A). 4 spines on inner ventral margin and 2 on outer ventral margin, fore and mid femurs without dorsal spines. Fore femur with 3 spines on inner ventral margin, mid femur with 4 outer ventral spines, hind femur with 9 spines on outer ventral margin and 3 on inner ventral margin. Hind tibia with 3 apical spurs on each side. Last abdominal tergite modified, enlarged and divided into two down-curved processes. Cerci up-curved, stout at their base with a fine black tip (Figs 4B, 4C); before the tip a second ramification of cerci branches off: the main base of cerci is $1.7 \mathrm{~mm}$ long, while the second branch is $2.6 \mathrm{~mm}$ long, out-curved and finely tipped (Figs 4B, 4C, 4D). Subgenital plate concave, long, without styli.

Distribution. Known from Kimpoko (Zaire), Democratic Republic of Congo, Cameroon, Fernando Poo (Guinea) (Karsch 1889, 1890, 1891, Griffini 1906, 1908, Sjöstedt 1912) and here reported from Gabon.
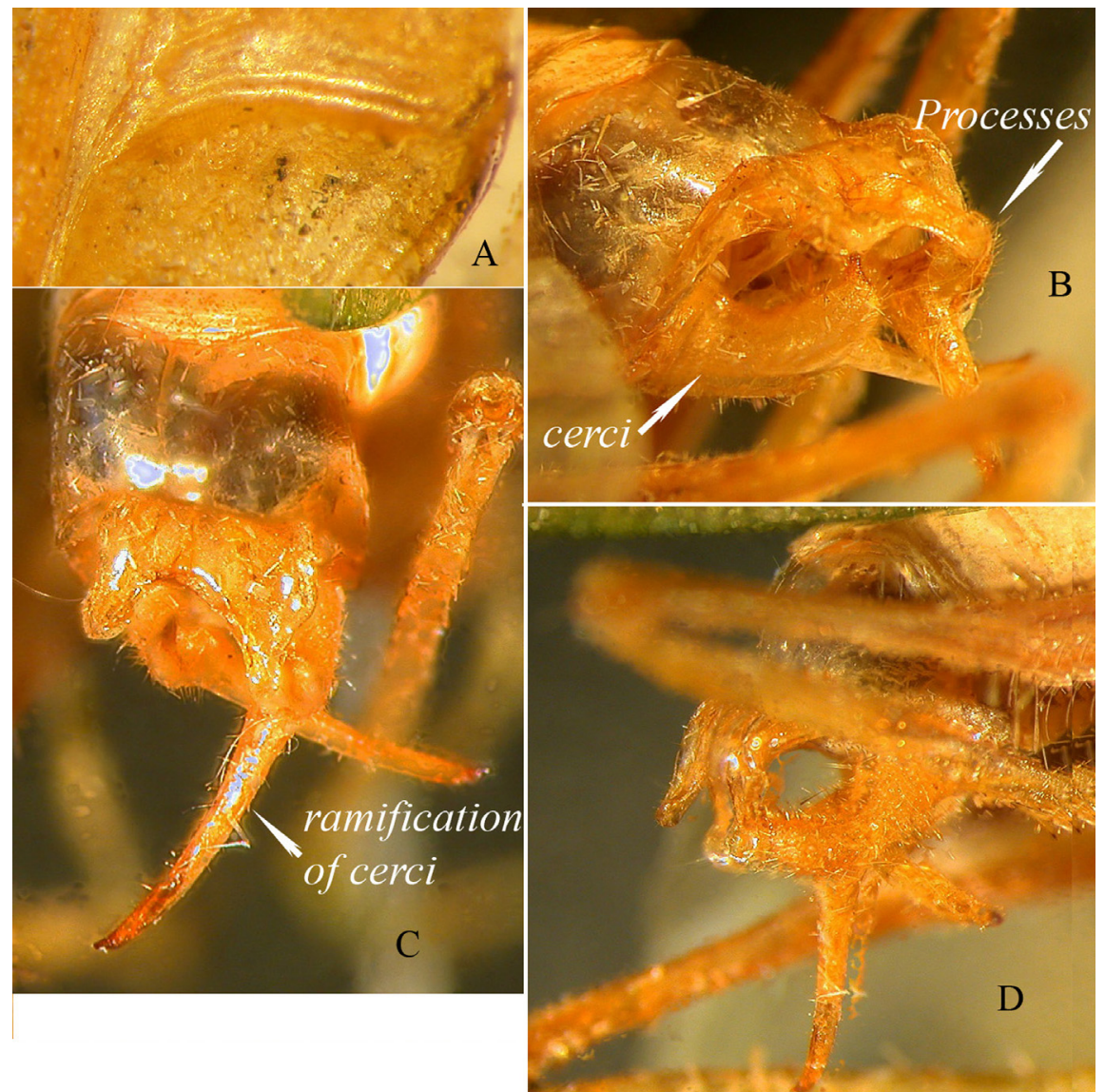

FIGURE 4. Eurycorypha spinulosa Karsch, 1889. A) Stridulatory file below the left tegmen of the male. B) Last tergite and cerci of the male. C) Cerci of the male from above. D) Lateral view of cerci of the male. 


\section{Eurycorypha listed by Griffini (1908)}

Figs $5 \mathrm{~A}-5 \mathrm{E}$ and $6 \mathrm{~A}-6 \mathrm{E}$

Material examined. Democratic Republic of Congo, Kinchassa (2 $\hat{\jmath}$ of different species) (RBINS).

Griffini (1908) reported the males of two unidentified species of Eurycorypha, whose characteristics did not match those of known species; however, he remarked that the description of many species of Eurycorypha was from the female sex, and consequently the above listed males could belong to species known only from females and consequently the above listed males could belong to species described only from the female sex. The opportunity to study the specimens listed by Griffini (1908) allowed to take some photographs of their characters, here presented in Figs 5 and 6 . This will consent in the future to ascertain if they belong to undescribed species or to species already described from the female sex. Recently the male of Eurycorypha flavescens (Walker, 1869) and Eurycorypha klaptoczi Karny, 1917 (both known only from the female sex) were described by Massa (2017b), who obtained a series of males and females collected together.

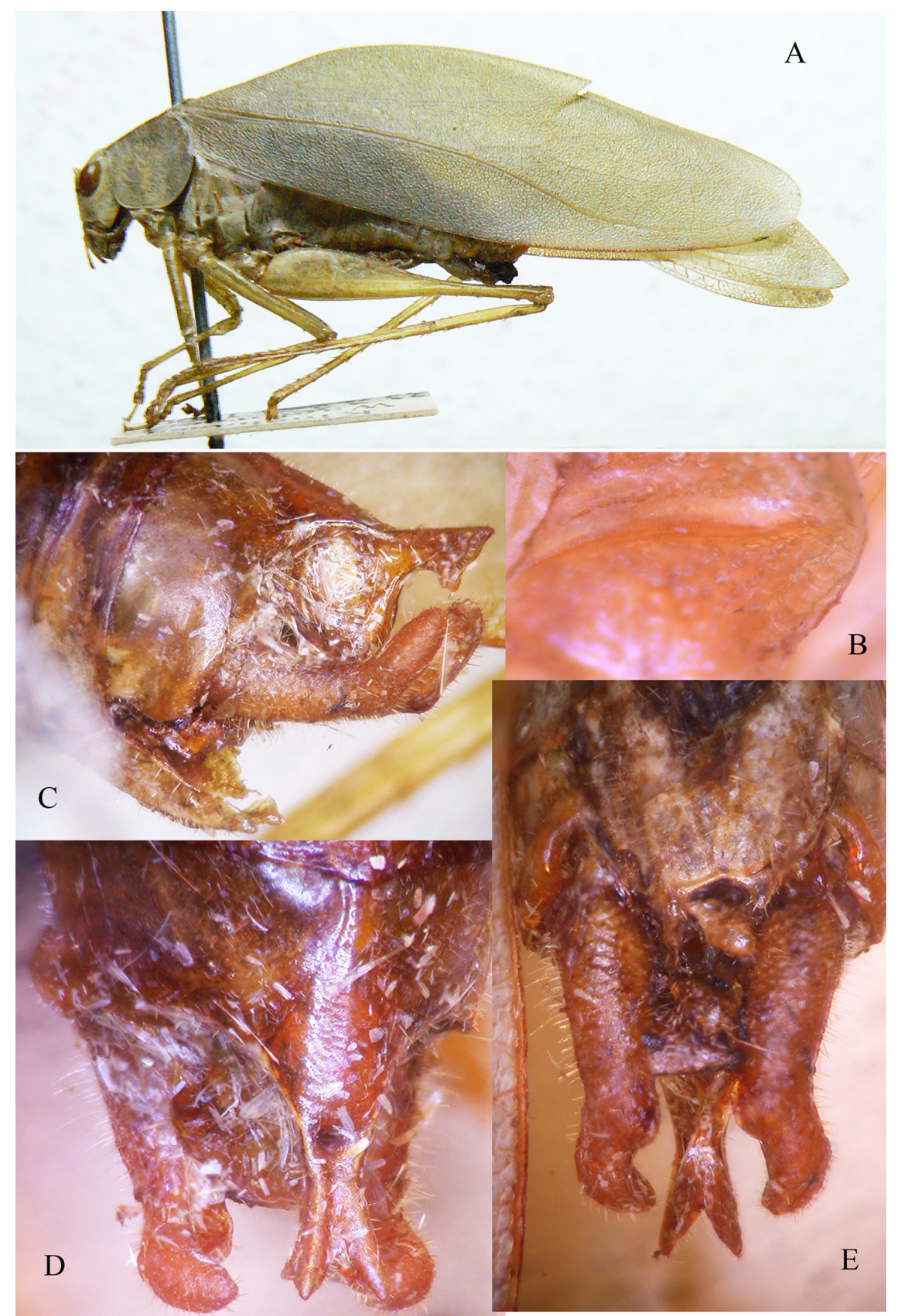

FIGURE 5. Eurycorypha sp.1 male from Griffini (1908). A) Lateral view of the specimen. B) Stridulatory file of the left tegmen. C) Lateral view of last abdominal segments. D) Dorsal view of the last tergite and cerci. E) Ventral view of the subgenital plate and cerci. 


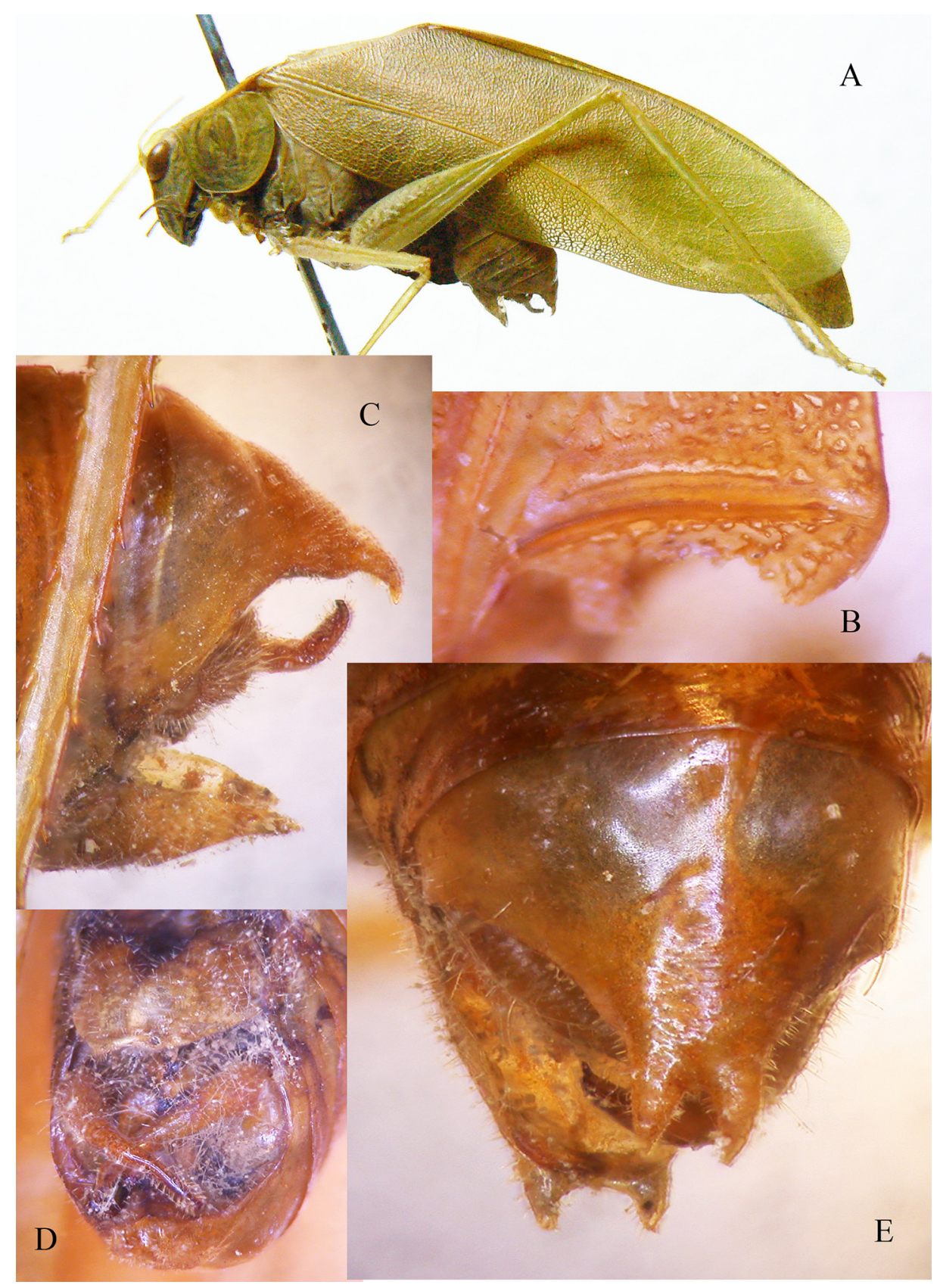

FIGURE 6. Eurycorypha sp.2 male from Griffini (1908). A) Lateral view of the specimen. B) Stridulatory file of left tegmen. C) Lateral view of last abdominal segments. D) Ventral view of the subgenital plate and cerci. E) Dorsal view of the last tergite.

Characters of the species cited by Griffini (1908) are the following.

Species 1. The stridulatory file is sinuous and consist of ca. 80 evenly spaced teeth. The anal segment has an horizontal compressed process, narrowed on the centre and well enlarged at the apex, where it is obliquely cut; it is vertically furrowed and divided into two short dorsal and two ventral tips. Cerci are broad, stout, up-bent after the centre as an elbow, well compressed and curved, apically obtuse. The subgenital plate is short, apically concave without styli (Figs 5A, 5B, 5C, 5D, 5E).

Species 2. The stridulatory file is curved and consists of ca. 90 evenly spaced teeth. The anal segment is attenuated from the base to the apex and ends with two parallel, rather broad, short and down-curved apices. Cerci are long and fine, incurved and pointed. The subgenital plate is rather large, apically concave, with short styliform appendices (Figs 6A, 6B, 6C, 6D, 6E). 
Tribe Tylopsidini Brunner von Wattenwyl, 1878

\section{Tylopsis irregularis Karsch, 1893}

Material examined. Madagascar, Ampasimbe, Onibé riv. 13.V.1993, A. Pauly $(1 \hat{\jmath}, 1$ \% $)$ (RBINS).

Remarks. Hitherto unreported from Madagascar.

\section{Tribe Pardalotini Brunner von Wattenwyl, 1878}

The genus Pardalota Brunner von Wattenwyl, 1878 may be recognized from Poecilogramma Karsch, 1887 by the less poorly developed fastigium of the vertex, that is a little wider than in Poecilogramma (Ragge 1980) (compare Fig. 7E with 9E). In addition, the strikingly variegated colour of Pardalota includes more or less wide round spots, while that of Poecilogramma consists of colored stripes. Another character that allows to separate the two genera is the shape of cerci, that are pointed and incurved in Pardalota, flat or rounded in Poecilogramma (compare Figs 7B, 7D, 7G with 9C, 9F).

\section{Pardalota asymmetrica Karsch, 1896}

Figs 7A, 7B

Karsch, 1896. Stett. Entomol. Z., 57: 330.

Material examined. Ruanda, Parc National Albert V. 1935, de Witte (32 $\overbrace{}^{\lambda}, 5$ 우) (RBINS).

Remarks. This species has the $10^{\text {th }}$ tergite modified and asymmetrical, divided into two lobes, the on the left is forked with one tip up-curved and the other down-curved, while the lobe on the right is only one and down-curved (after this character the name asymmetrica was coined) (Fig. 7B). This character is also in common with $P$. karschiana Enderlein, 1907 (Figs 7F, 7G) and P. versicolor Brunner von Wattenwyl, 1878 (Fig. 8A). In addition, cerci of $P$. asymmetrica are expanded and spoon-shaped on the inside, with a terminal sharp part and a lateroexternal appendix. Similar cerci are found in P. superba Sjöstedt, 1913 (Fig. 8C).

Distribution. P. asymmetrica was hitherto known from Uganda, Tanzania, Democratic Republic of Congo and Zambia (Karsch 1896, Heller et al. 2014, Massa 2015, 2016).

\section{Pardalota haasi Griffini, 1908}

Figs 7C, 7D, 7E

Griffini, 1908. Mem. Soc. entomol. Belgique, 15: 76.

Material examined. Democratic Republic of Congo, Luluabourg, C. Haas (2 $\hat{\gamma}, 1+$ syntypes); Democratic Republic of Congo, Mabwe (485 m) 3-12.I.1949 (3 $\hat{\gamma}, 3$ ) ; Democratic Republic of Congo, Elisabethville (now Lubumbashi) I.1939, H.J. Brédo (3今); Democratic Republic of Congo, N Kosso Norma, Lac Tumba 31.XII.1938 $(1 \hat{\jmath})$; Democratic Republic of Congo, R. Kanzenze-Lualaba 1948, R.P. Lefebure $(2 \hat{\jmath}, 2$ ) $)$ (RBINS).

Remarks. Cerci of $P$. haasi are pointed and incurved, the $10^{\text {th }}$ tergite is not modified (Fig. 7D).

Distribution. It is known only from Democratic Republic of Congo (Griffini 1908).

\section{Pardalota karschiana Enderlein, 1907}

Figs $7 \mathrm{~F}, 7 \mathrm{G}$

Enderlein, 1907. Zool. Jahrb. Abt. Syst. Geogr. Und Biol. Tiere, 25: 197.

Material examined. Democratic Republic of Congo, Inongo (1 9 ); Democratic Republic of Congo, Elisabethville (now Lubumbashi) 27.I.1951, C. Seydel (1ð) (RBINS). 
Remarks. Cerci of P. karschiana are incurved, with pointed tip (Fig. 7G). The female of this species was first described by Griffini (1908).

Distribution. Described from Tanzania (Enderlein 1907), later found also in the Democratic Republic of Congo.
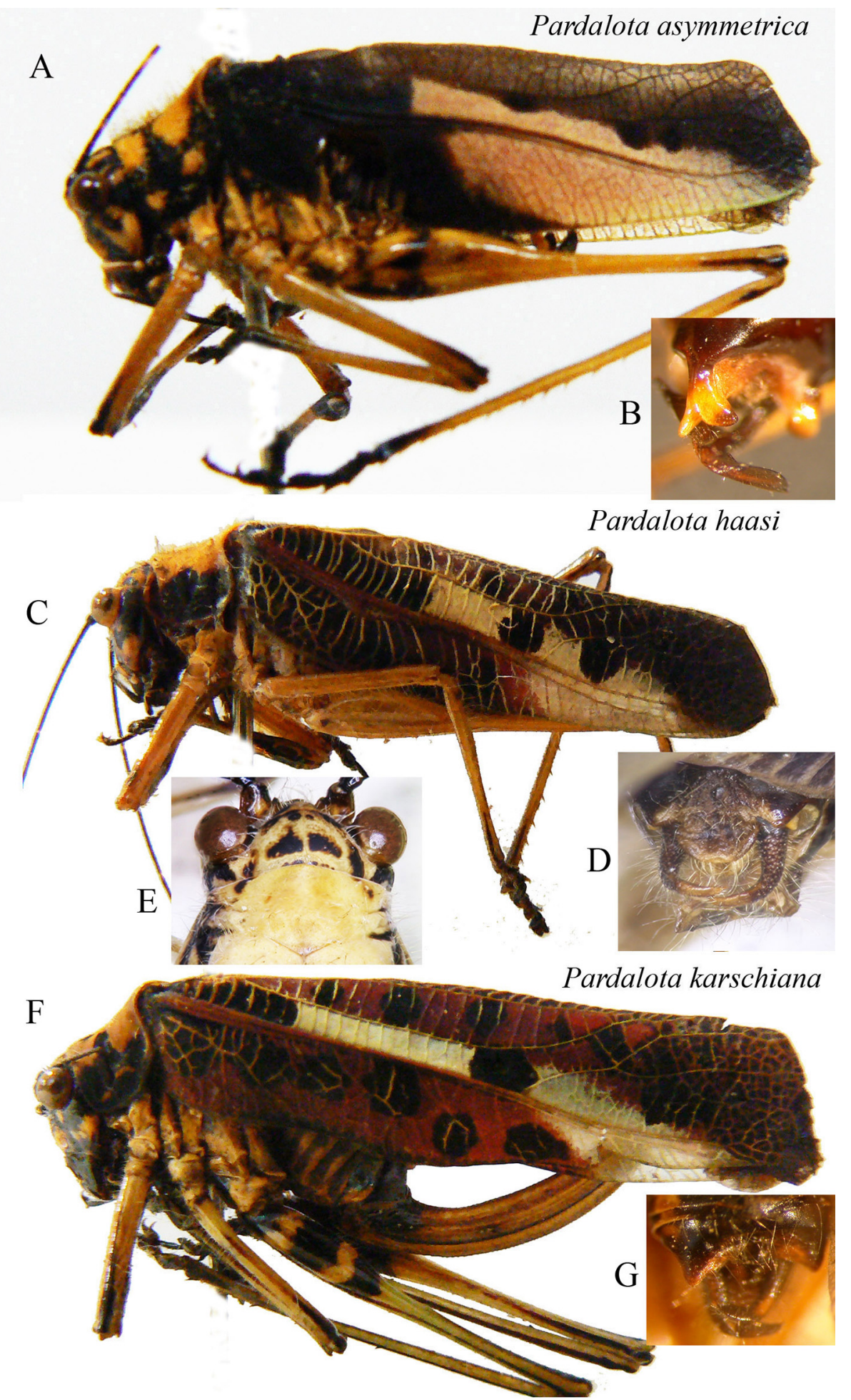

FIGURE 7. A) Lateral view of the male Pardalota asymmetrica Karsch, 1896. B) Last tergite and cerci of the same in dorsal view. C) Lateral view of the male Pardalota haasi Griffini 1908. D) Last tergite and cerci of the same in dorsal view. E) Dorsal view of the head and pronotum of the same. F) Lateral view of the female Pardalota karschiana Enderlein, 1907. G) Dorsal view of last tergite and cerci of male of the same. 


\section{Pardalota versicolor Brunner von Wattenwyl, 1878}

\section{Fig. 8A}

Brunner von Wattenwyl, 1878. Monographien der Phaneropteriden, 134.

Material examined. Democratic Republic of Congo, Mpese II-IV.1937 (1 $\left.{ }^{\Uparrow}\right)$; Democratic Republic of Congo, Rivière Quillou, Loango XII.1892 (1 $\left.{ }^{\Uparrow}\right)$; Democratic Republic of Congo, Lukungu (1 ) $)$; Democratic Republic of Congo, Mayumbe 28.V.1952 (1 9 ) (RBINS)

Distribution. Described from Chinchoxa in Benguela (Angola) (Brunner von Wattenwyl 1878), known also from the Democratic Republic of Congo (Giglio-Tos 1907, Griffini 1908).
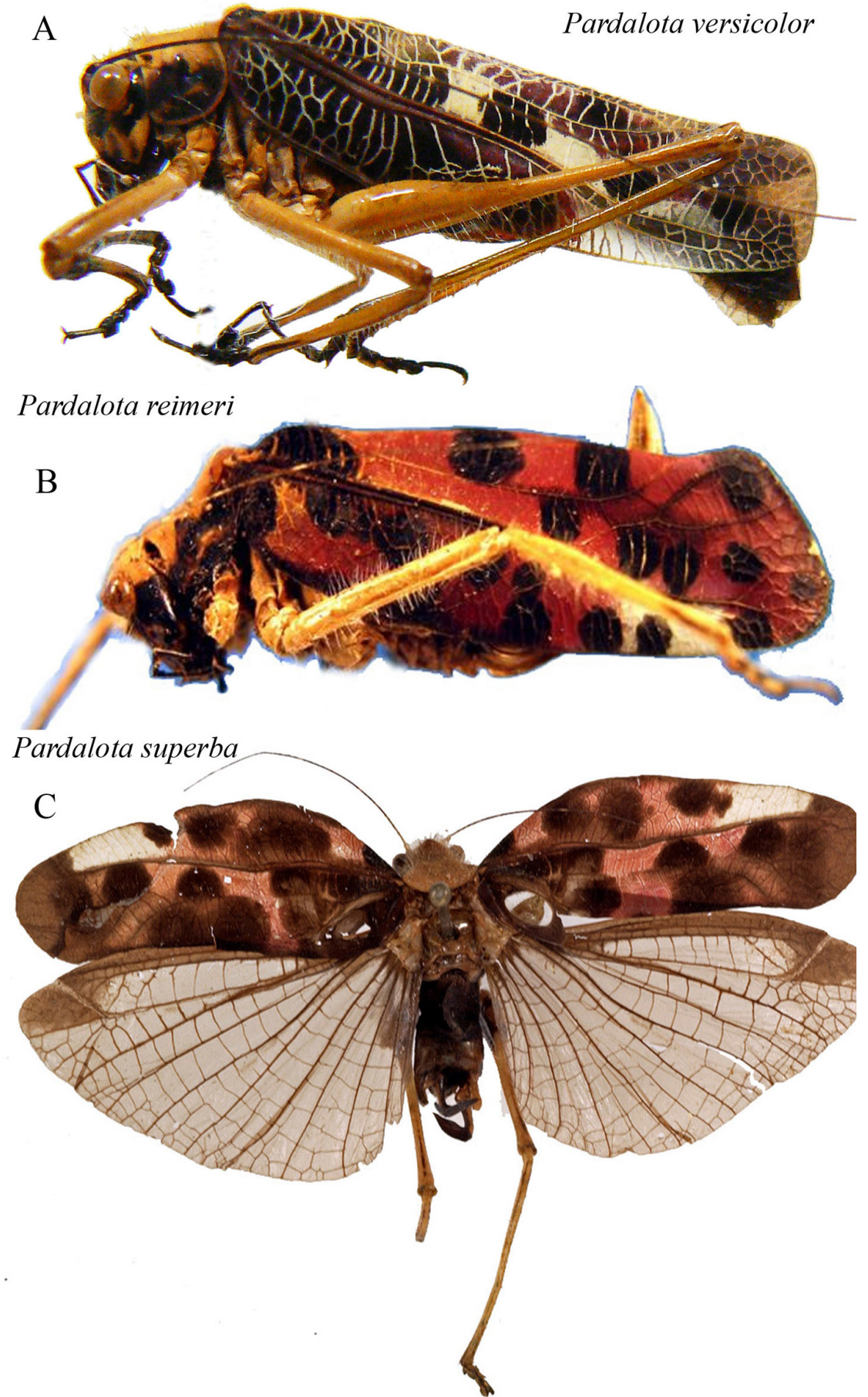

FIGURE 8. A) P. versicolor Brunner von Wattenwyl, 1878 male in lateral view. B) Pardalota reimeri La Baume, 1911 female in dorsal view. C) Pardalota superba Sjöstedt, 1913 male in lateral view. 


\section{Poecilogramma cloetensi (Griffini, 1908)}

Figs 9A

Griffini, 1908. Mem. Soc. entomol. Belgique, 15: 77.

Material examined. Democratic Republic of Congo, Beni Bendi Sankuru 1895, L. Cloetens ( $q$ holotype) (RBINS); Democratic Republic of Congo, Hombo 31.XII.1960, T. De Stefani (1q) (MRT); Gabon, Sette Cama, VII.1976, P. Moretto (1 + ) (BMCP).

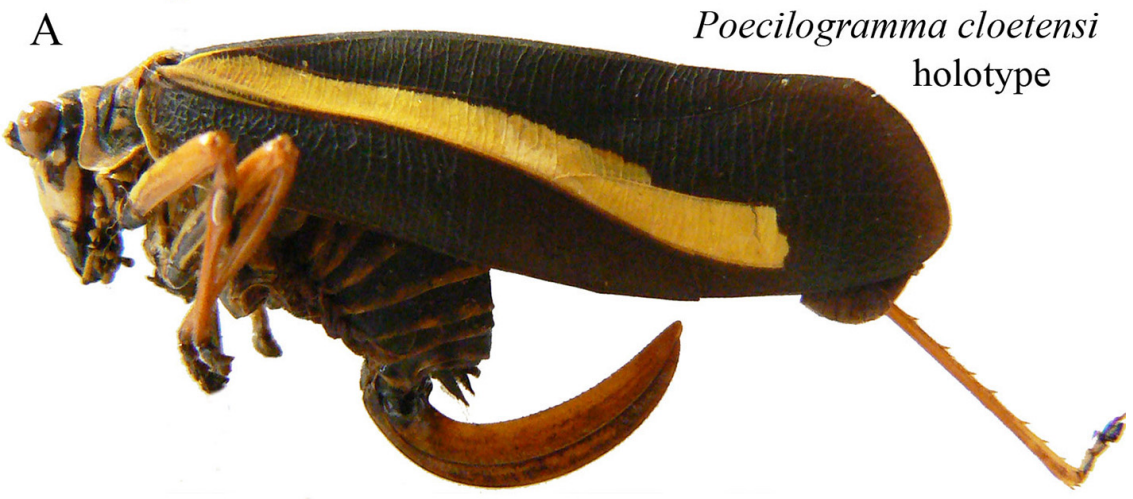

Poecilogramma striatifemur

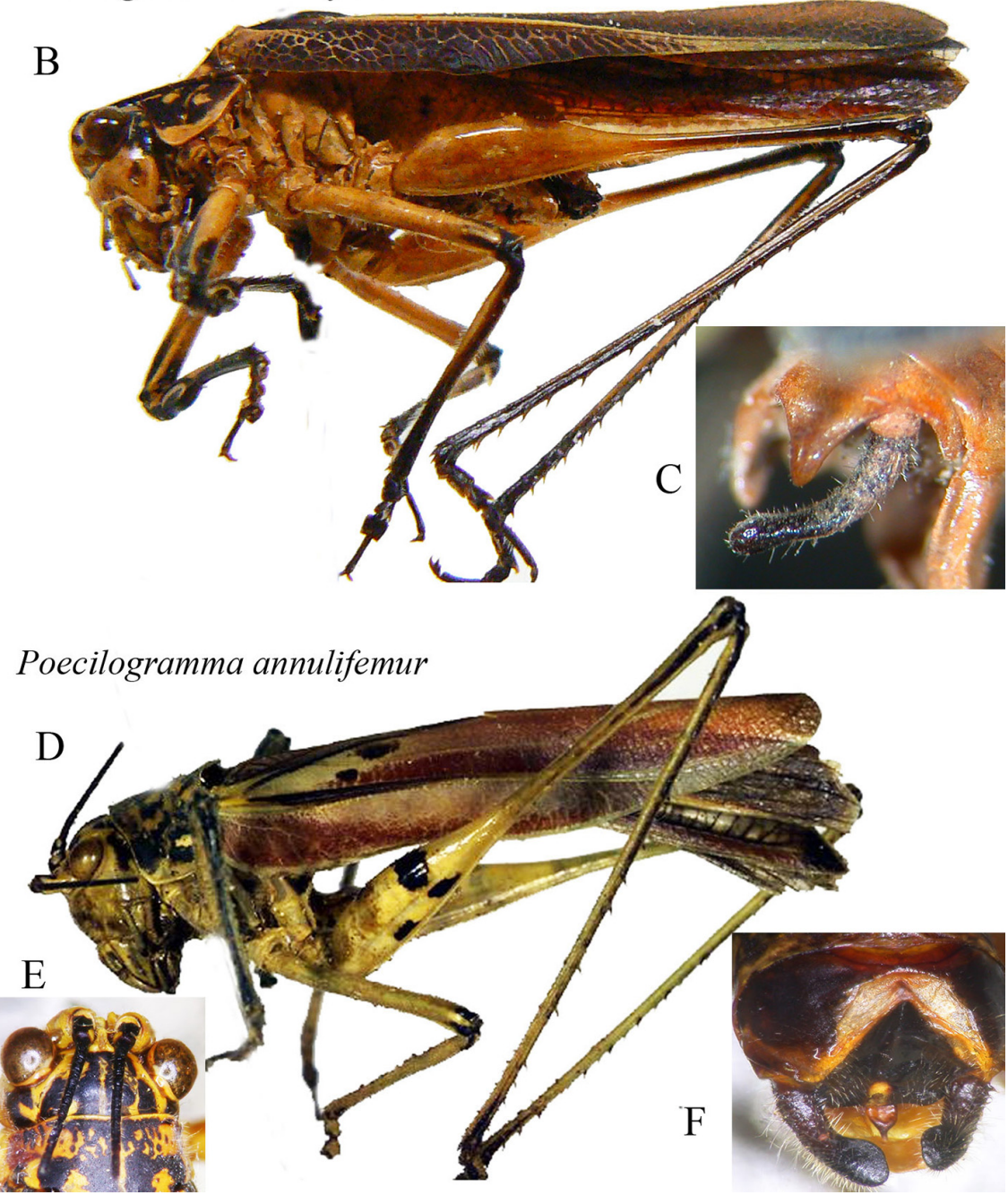

FIGURE 9. A) Poecilogramma cloetensi (Griffini, 1908) holotype female in lateral view. B) Poecilogramma striatifemur Karsch, 1887 male in lateral view. C) Dorsal view of the last tergite and cerci of the same. D) Poecilogramma annulifemur Karsch, 1887 male in lateral view. E) Dorsal view of the head and pronotum of the same. F) Dorsal view of the last tergite and cerci of the same. 
Remarks. Described within the genus Pardalota, it was transferred to Poecilogramma by Ragge (1980) for its very narrow shape of the fastigium of vertex.

Distribution. Described from the Democratic Republic of Congo (Griffini 1908), found in Gabon (Massa 2013); according to Ragge (1980) it is present from Cameroon to Zaire.

\section{Poecilogramma annulifemur Karsch, 1887}

Figs 9D, 9E, 9F

Karsch, 1887. Entom. Nachricht., 13: 53.

Material examined. Democratic Republic of Congo, Kalulu 6.V.1939, H.J. Brédo (1ðึ); Democratic Republic of Congo, Ngowa Kwango 11.V.1939, J. Mertens (4ત, 1 우) (RBINS).

Remarks. P. annulifemur differs from P. striatifemur Karsch, 1887 , other than by the colour, also by its $10^{\text {th }}$ tergite (compare Figs 9C with 9F). Within Pardalotini, $P$. annulifemur is the only species, whose female ovipositor has inferior and superior tips toothed. Other species have smooth apex of the ovipositor.

Distribution. Previously known only from Tanzania (Karsch 1887, 1889), newly recorded in the Democratic Republic of Congo.

\section{Tribe Terpnistrini Brunner von Wattenwyl, 1878}

\section{Terpnistriella n. gen.}

Figs $10 \mathrm{~A}-10 \mathrm{H}$

Species type of the genus: Terpnistriella bredoi $\mathbf{n}$. sp., here designated.

Description. Head without fronto-genal carinae. Fastigium of vertex compressed, narrower than first antennal segment, sloping steeply to frons, sulcate above. Eyes round, prominent, wider than subocular groove. Pronotum straight along anterior margin, without median carina; lateral carinae visible in posterior part, mainly after pronotum excision; surface smooth. Fore coxae with spine. Fore and mid femora unarmed. Hind femora with some large and broad-based ventral spines. Fore tibiae with closed tympanum on inner and open on outer side. Fore and mid tibiae with dorsal spurs on outer margin. Hind tibiae with three apical spurs on each side. Both pairs of wings fully developed. $10^{\text {th }}$ abdominal tergite of male unmodified. Male subgenital plate without styli.

Remarks. Even if Terpnistria Stål, 1873 has the open tympanum on the inner side of the fore tibiae, Terpnistriella $\mathrm{n}$. gen. is seemingly related to the former, from which main differences are the absence of frontogenal carinae, the pronotum margins not raised, closed tympana on anterior tibiae, and second pair of wings coloured. Thus, it is tentatively placed in the tribe Terpnistrini.

Etymology. The name Terpnistriella is a diminutive of Terpnistria.

\section{Terpnistriella bredoi $\mathrm{n} . \mathbf{s p}$.}

Figs $10 \mathrm{~A}-10 \mathrm{H}$

Material examined and depository. Democratic Republic of Congo, Elisabethville (now Lubumbashi) 27.IV.1939, H.J. Brédo (light) ( ${ }^{\Uparrow}$ holotype, $1{ }^{\Uparrow}$ paratype) (RBINS).

Measurements. Male. Body length: 21.0-21.5; length of pronotum: 5.9-6.0; height of pronotum 5.0-5.1; length of tegmina: 37.9-38.5; width of tegmina: 8.2-8.5; length of hind femora: 26.0-26.7; length of hind tibiae: 28.0-29.3.

Diagnosis. Very characteristic for its hind femora with 10-11 ventral spines in both margins, of which the last 3-4 are large, broad-based and expand into flat, pointed lobes, pronotum without raised margins and hind wings with a wide reddish patch. 


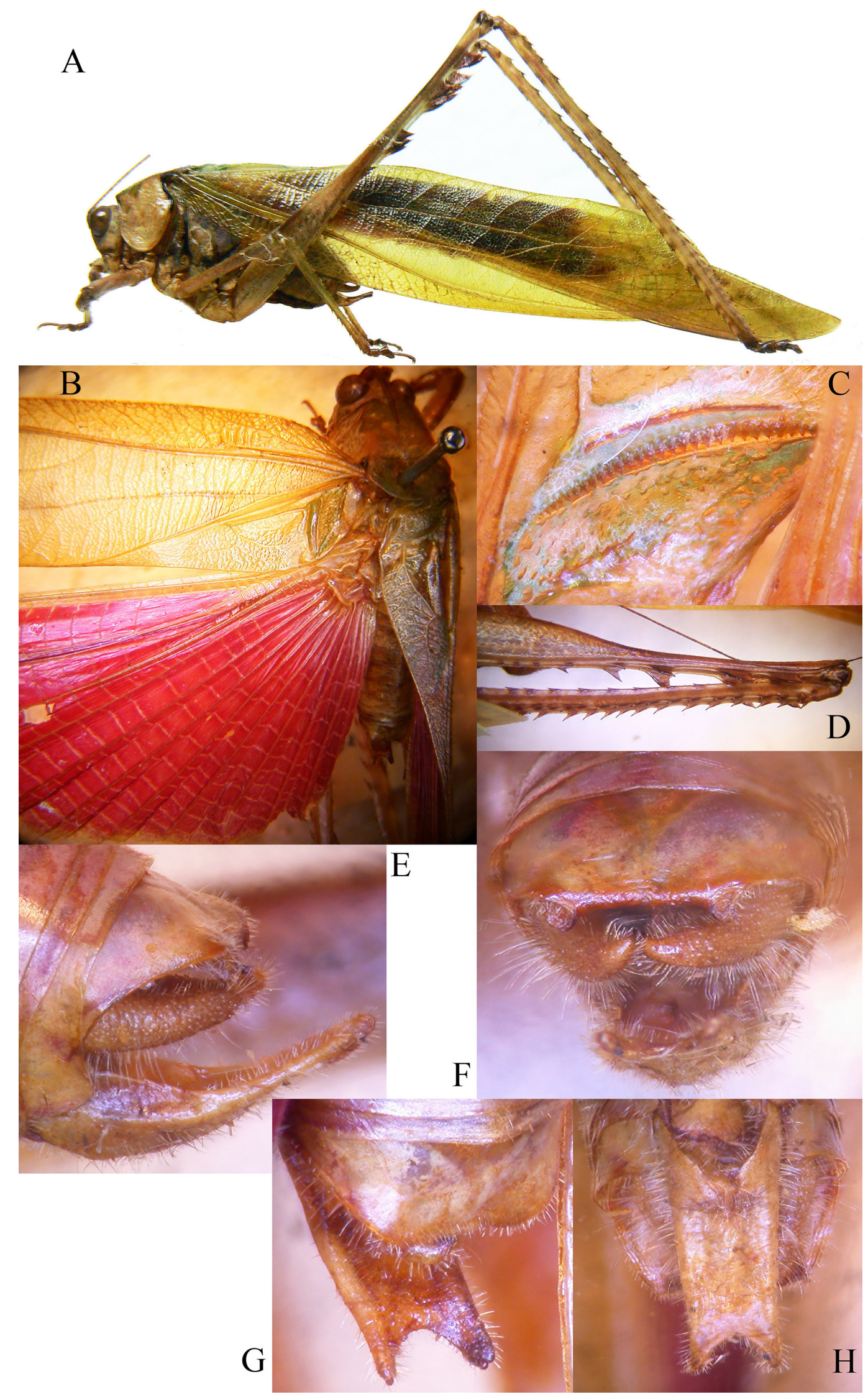

FIGURE 10. Terpnistriella bredoi n. gen. n. sp. A) Lateral view of the male paratype. B) Dorsal view of stridulatory area and wings of the male holotype. C) Stridulatory file of the holotype. D) Lateral view of hind legs of the holotype. E) Lateral view of the last abdominal segments of the holotype. F) Dorsal view of the last tergite and cerci of the holotype. G) Dorsal view of the subgenital plate of the holotype. H) Ventral view of the subgenital plate of the holotype. 
Description of the male. Colour. Body yellowish, posterior margin of pronotum lobes black, lateral mesosternum black, tarsi blackish, spine of femora black, those broad-based only black on superior margin (Fig. 10A). 4-5 brown spots on posterior part of tegmina, second pair of wings with a wide reddish area (Fig. 10B). Head without fronto-genal carinae. Fastigium of vertex compressed, narrower than first antennal segment, sloping steeply to frons, sulcate above. Eyes round, prominent, wider than subocular groove. Pronotum straight along anterior margin, without median carina; lateral carinae just visible in the posterior part, mainly after pronotum excision; surface smooth and covered by small pilosity. Fore coxae armed with a fine spine. Fore and mid femora unarmed. Hind femora with 10-11 ventral spines in both margins, of which the last 3-4 are large, broad-based and expanded into flat, pointed lobes (Fig. 10D). Fore tibiae with closed tympanum on inner and open on outer side, with 4 spines on ventral margins, and 1-2 on outer dorsal margin +1 spur. Mid tibiae with 8 spines on ventral margins and $3+1$ spur on inner dorsal margin. Hind tibiae with 18-20 ventral spines on both margins and ca. 30 broad-based small spines on dorsal margins +3 apical spurs on each side (Fig. 10D). Both pairs of wings fully developed. Stridulatory area of left tegmen a little elevated above wing plane (Fig. 10B); stridulatory file curved, $1.8 \mathrm{~mm}$ long and consisting of ca. 30 teeth evenly spaced (Fig. 10C). $10^{\text {th }}$ abdominal tergite straight with two lateral small down-curved tips (Figs 10E, 10F). Cerci stout, in-curved and pointed (Figs 10E, 10F). Subgenital plate upcurved, narrow, long, tri-carinate and apically concave, styli absent (Figs 10G, 10H).

Etymology. This species is dedicated to the late H.J. Brédo, collector on behalf of the Royal Belgian Museum in the Democratic Republic of Congo and other tropical African countries; he collected series of very interesting Orthoptera and other orders of Insecta, among which specimens are two new genera here described.

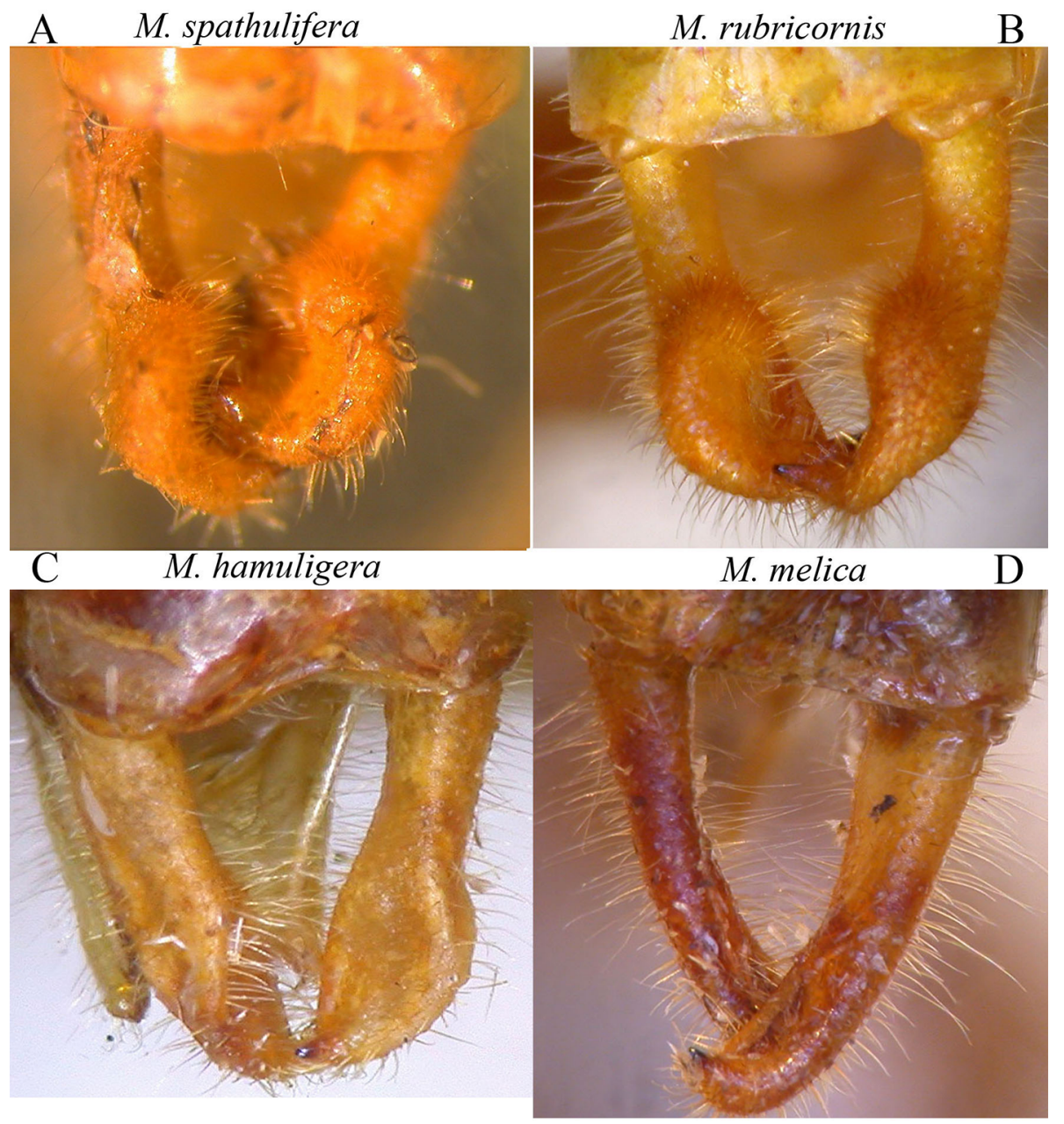

FIGURE 11. Dorsal view of male cerci in Morgenia species. A) Morgenia spathulifera Griffini, 1908 holotype. B) M. rubricornis Sjöstedt, 1913. C) M. hamuligera Karsch, 1890. D) M. melica Karsch, 1893. 


\section{Morgenia spathulifera Griffini, 1908}

Material examined. Democratic Republic of Congo, Bussanga 14.XI.1905 (1 $\overbrace{}^{\Uparrow}$ syntype); Cameroon, Mukonje Farm, R. Rohde (1 $\bigcirc$ syntype); Cameroon, Mt Koupé 31.I-8.II.1983, J. van Stalle (1ð̊); Democratic Republic of Congo, Ngowa 9.I.1939, J. Mertens (1ठ) (RBINS); Ivory Coast, Taï Nat. Park, Res. Station 13.III.2017, B. Massa

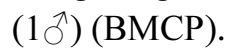

Remarks. Five species are known in the genus Morgenia Karsch, 1890, namely: M. hamuligera Karsch, 1890, M. melica Karsch, 1893, M. modulata Karsch, 1896, M. rubricornis Sjöstedt, 1913 and M. spathulifera Griffini, 1908. Cerci of the latter species (Fig. 11A) are quite similar to those of M. rubricornis (Fig. 11B) and M. hamuligera (Fig. 11C), but M. spathulifera may be easily separated from the other two species by the ratio length/ width of tegmina (6.6-6.7 in M. spathulifera, 5.5-5.6 in M. hamuligera and M. rubricornis). Cerci of M. melica and M. modulata are very similar between them (those of M. modulata are more slender apically than those of $M$. melica), but they clearly differ from those of the previous three species (compare Figs 10D with 10A, 10B, 10C). In addition, the shape of the male subgenital plate (Figs 12A-12D) and of the stridulatory file (Figs 13A-13D) allow to tell apart them. M. spathulifera is also characterized by the presence of small grey dots on tegmina.

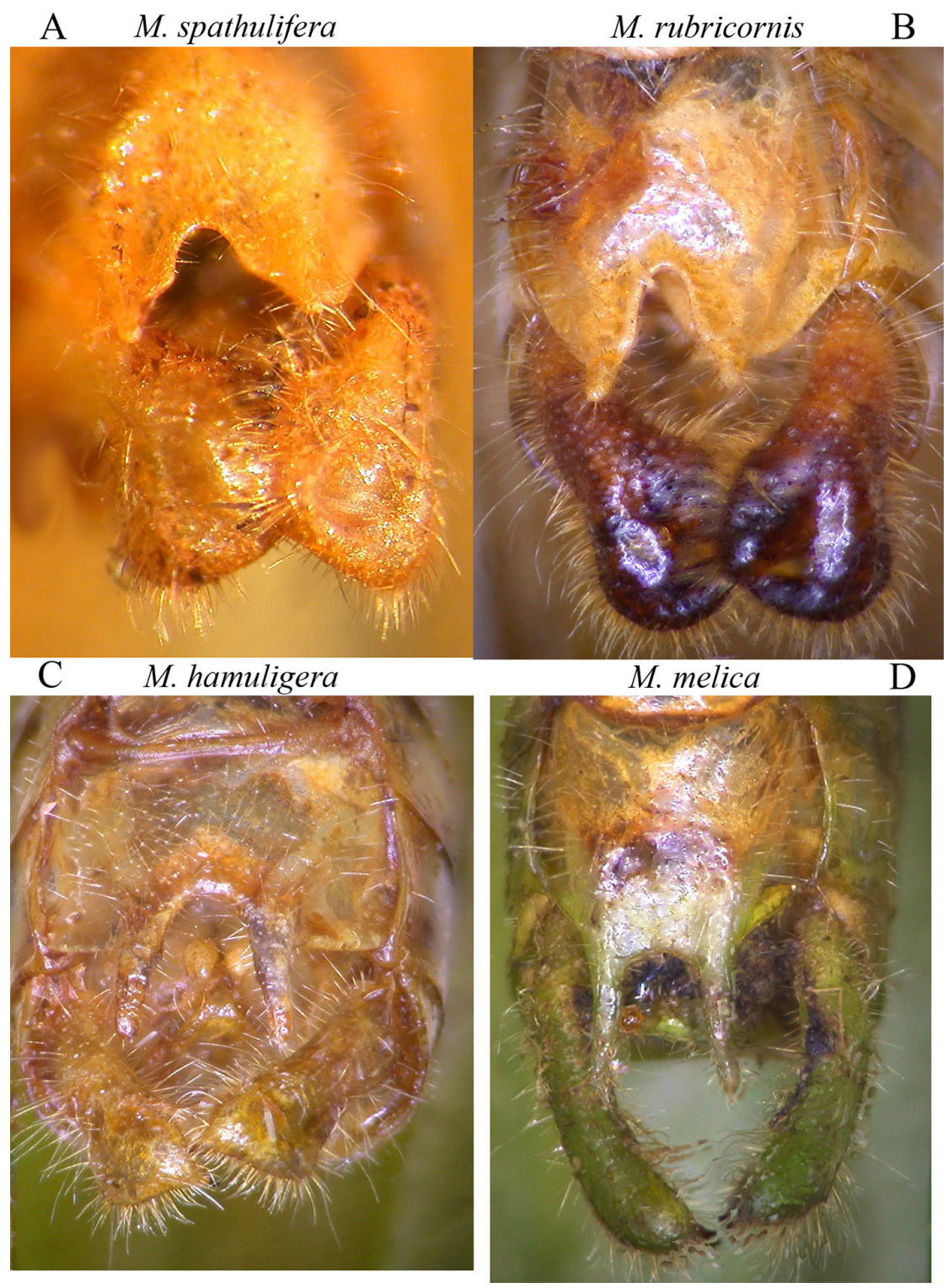

FIGURE 12. Ventral view of the male subgenital plate and cerci in Morgenia species. A) Morgenia spathulifera Griffini, 1908 holotype. B) M. rubricornis Sjöstedt, 1913. C) M. hamuligera Karsch, 1890. D) M. melica Karsch, 1893. 


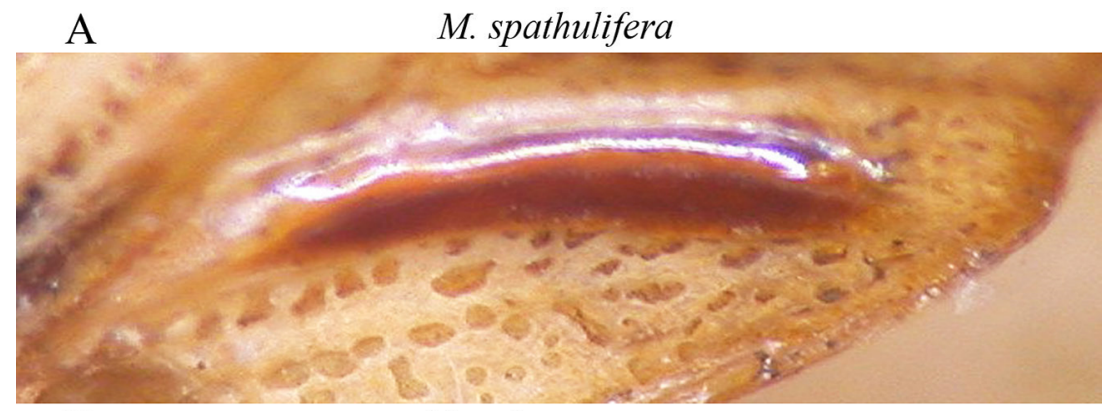

$\mathrm{B}$

M. rubricornis

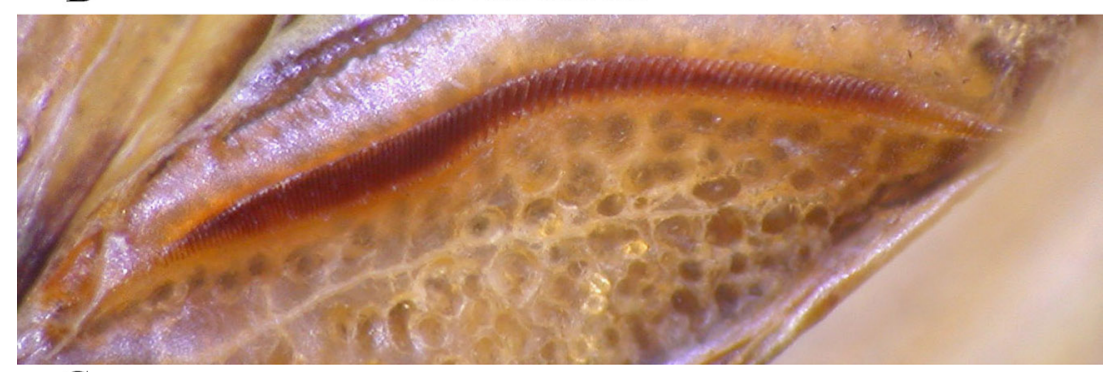

C M. hamuligera

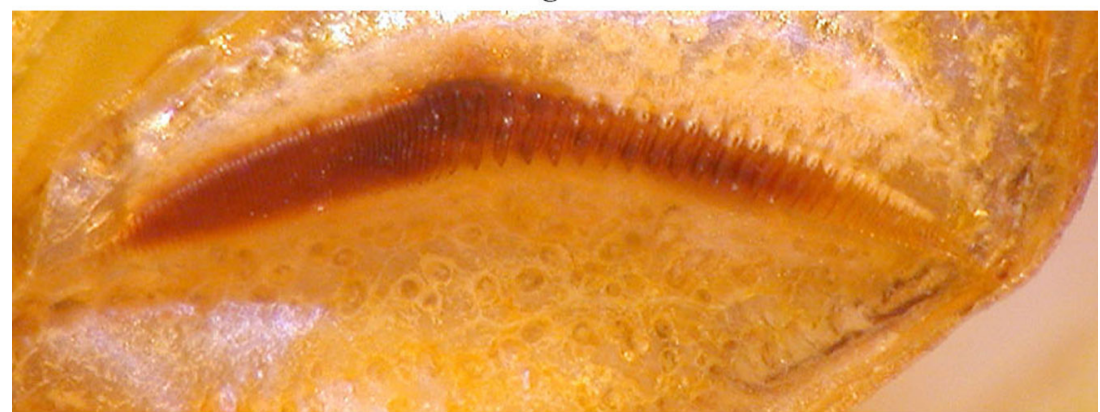

$\mathrm{D}$

M. melica

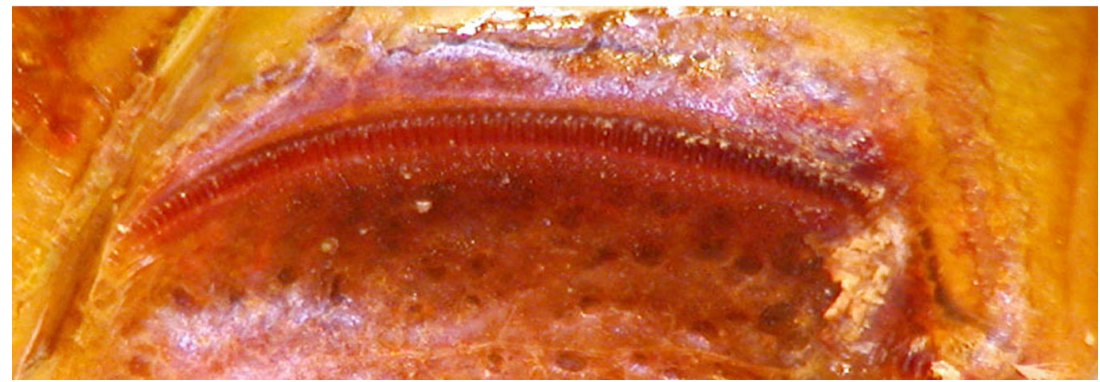

FIGURE 13. Stridulatory file of left tegmen in Morgenia species. A) Morgenia spathulifera Griffini, 1908 holotype. B) M. rubricornis Sjöstedt, 1913. C) M. hamuligera Karsch, 1890. D) M. melica Karsch, 1893.

Distribution. M. spathulifera is presently known from Cameroon, Democratic Republic of Congo and Ivory Coast.

\section{Tribe Plangiopsini Cadena-Castañeda, 2015}

Cadena-Castañeda (2015) proposed to transfer Plangiopsis adeps to the genus Plangiola Bolívar, 1906 for the cooccurrence of the denticulation on lateral carinae of pronotum with $P$. herbacea Bolívar, 1906. However, syntypes of $P$. adeps (MfN, Berlin) do not present the above cited denticulation. Thus, it seems appropriate to leave adeps within the genus Plangiopsis. 


\section{Plangiopsis adeps Karsch, 1896}

Karsch, 1896. Stett. Entomol. Z., 57: 338.

Type locality: Cameroon, Lolodorf, L. Conradt (syntypes females) (MfN).

Plangiopsis shoutedeni Griffini, 1908 n. syn.

Griffini, 1908. Mem. Soc. entom. Belgique, 15: 218.

Type locality: Cameroon, Mukonje Farm, R. Rohde (holotype female) (RBINS).

Material examined. P. adeps. Cameroon, Lolodorf, L. Conradt ( $2 \uparrow$ syntypes) (MfN); Ivory Coast, Sassandra

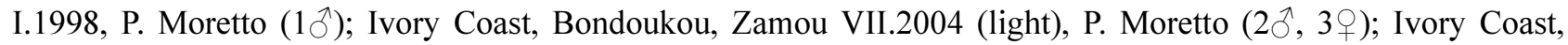
Zamou 6-7.VI.2015, P. Moretto (1ð̄, 1 + ); Ivory Coast, Mt Tonkoui (1200 m) 1-2.VII.2014, 18-20.VI.2015, 2428.VII.2015, 21.X.2015 (light), P. Moretto (4q); Ivory Coast, Taï Nat. Park, Res. Station, 14-24.III.2017 (light), B.

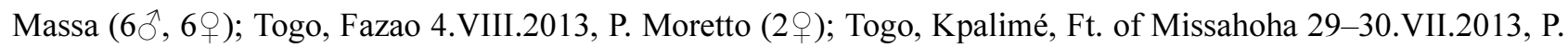
Moretto (1ð); Central African Republic, Ndoki 10.II.2012, 28-29.II.2012, 29.II-1.III.2012 (light), P. Moretto (1ðै, $2 \bigcirc$ ) (BMPC). P. shoutedeni. Cameroon, Mukonje Farm, R. Rohde ( $\odot$ holotype) (RBINS).

Remarks. $P$. shoutedeni was described from only one female. According to Griffini (1908) it differs from $P$. adeps Karsch, 1896 by the number of veinlets branching off from the radial vein of tegmina (Figs 14A, 14B). They are three, all placed after the centre of tegmina; however, in $P$. adeps this character is variable, generally there are three, but some specimens may have two or four. The fastigium of vertex of $P$. shoutedeni is ca. two times as large as the first antennal segment (Fig. 14C), while in most $P$. adeps it is three times as large as the first antennal segment (Fig. 14D); however, this character may be also variable and some specimens of $P$. adeps may present a fastigium less large. Also the ovipositor of the two species resulted very similar (Figs 14E, 14F). For these reasons it is here that a new synonymy is proposed: Plangiopsis shoutedeni Griffini, 1908 = Plangiopsis adeps Karsch, 1896.

\section{Phaneropterinae of uncertain tribe}

\section{Gen. Mimoscudderia Carl, 1914}

The genus Mimoscudderia is characterized by fastigium of vertex narrow, furrowed, not contiguous with fastigium of frons, eyes semi-spherical (higher than large), pronotum rounded in metazona, little enlarged in prozona, tegmina rather narrow, all femora inferiorly armed, hind genicular lobes provided with two small spines, and styli absent. It is known only from Madagascar, where Carl (1914) described two species, one of which only from a female, the other from both sexes; recently Massa (2017a) described a third species, which tentatively he has placed within this genus.

\section{Mimoscudderia picta Carl, 1914}

Figs 15A, 15C, 15D, 15G, 15I

Carl, 1914. Rev. Suisse Zool., 22 (6): 160.

Material examined. Madagascar, Marantsetra (1 $\left.\delta^{\Uparrow}\right)$; Madagascar, Manakambahiny forest II.1991, A. Pauly (1 + ) (RBINS).

Measurements (after Carl 1914, in parenthesys). Male. Body length: 23.5 (20.0); length of pronotum: 5.1 (5.5); height of pronotum 5.0; length of tegmina: 40.2 (41.0); width of tegmina: 7.1 (7.0); length of hind femora: 28.2 (27.0); length of hind tibiae: 32.0. Female. Body length: 18.4 (20.0); length of pronotum: 5.3 (5.0); height of pronotum 5.7; length of tegmina: 41.4 (44.0); width of tegmina: 7.0 (8.0); length of hind femora: 28.6 (30.0); length of hind tibiae: 32.6 ; ovipositor: $9.3(9.0)$.

Remarks. Since its description (Carl 1914) no data have been reported about this species. The following are the sexual characters, only superficially listed by Carl (1914). The subgenital plate of the male is long and upcurved, cerci are as long as the subgenital plate, incurved with pointed tip (Figs 15A, 15C, 15D). The stridulatory 
file is curved and consists of ca. 80 teeth, central higher than distal ones, a bulge in proximal part (Fig. 15G). The ovipositor of the female is gently up-curved, with superior margin and the tip of inferior margin toothed (Fig. 15I).

\section{Mimoscudderia paulyi new species}

Figs 15B, 15E, 15F, 15H

Material examined. Madagascar, Manakambahiny, A. Pauly ( $\delta^{\Uparrow}$ holotype) (RBINS).

Measurements. Male. Body length: 25.0; length of pronotum: 4.7; height of pronotum 4.0; length of tegmina: 45.6; width of tegmina: 12.1; length of fore femora: 7.7; length of hind femora: 24.1; length of hind tibiae: 28.0.

Diagnosis. Mimoscudderia paulyi n. sp. is characterized by larger size and wider tegmina than congeneric species; additionally it has a modified $10^{\text {th }}$ tergite and a long and up-curved subgenital plate.

Description of the male (Figs 15B, 15E, 15F, 15H). Species of large size. Colour. Anterior margin of tegmina black, tegmina yellow with brown wide spots. Fastigium of vertex narrow, furrowed above, clearly separated by fastigium of frons. Eyes just semi-spherical, well projecting, without fronto-genal carinae below them. Legs comparatively long. Fore coxae armed with a small spine. Fore tibiae furrowed superiorly, distinctly widening above tympanum, which is open on both sides. Fore femora armed with 8 inner ventral spines, mid tibiae with 9 spines on outer ventral margin and unarmed inner ventral margin, hind femora armed ventrally with 7 spines on inner and 9 on outer margins, hind tibiae with many spines on ventral and dorsal margins +3 spurs on each side. All femora with armed genicular lobes. Pronotum narrowing anteriorly, flat above, anterior margin straight, posterior margin just rounded, humeral sinus evident, lobes of pronotum rounded and short. Tegmina widened with rounded apices. Wings just as long as tegmina. Stridulatory area of left tegmen short, stridulatory file curved and consisting of ca. 80 teeth, proximal higher and distal smaller (Fig. $15 \mathrm{H}$ ). $10^{\text {th }}$ tergite modified, consisting of a double bulge with a wide concavity, where the subgenital plate is inserted. Cerci stout, straight, with a small inner apical spine. Subgenital plate very long, narrow and up-curved to the concavity of the $10^{\text {th }}$ tergite, styli absent (Figs $15 \mathrm{~B}, 15 \mathrm{E}, 15 \mathrm{~F})$.

Diagnosis. According to Carl (1914, translated from Latin), who described the female of M. modesta, it differs from M. picta by its smaller size (body length: 16.0; length of tegmina: 39.0; width of tegmina: 7.5; length of fore femora: 8.0; length of hind femora: $26.0 \mathrm{~mm}$ ), colour slightly variegated, pronotum lobes higher than long, and ovipositor less up-curved. Concerning the colour of M. modesta, the pronotum is ochreous, with one-colored metazona, posterior margin of pronotum blackish, posterior margin of tegmina brown, absence of black rings on legs and upper fore tibiae darkish. The male above listed of $M$. paulyi n. sp. is of a larger size than the male of $M$. picta (see above measurements of this species) and the female of M. modesta, has much longer and wider tegmina than the male and the female of M. picta and the female of M. modesta, has the anterior margin of tegmina black, tegmina yellow with brown wide spots. Thus, differences may allow to exclude the possibility that it might be the male of M. modesta. Differences from the other known species M. modesta Carl, 1914, M. picta Carl, 1914 and M. spinicercata Massa, 2017 are based on the colour and shape of tegmina, but mostly (at least for M. picta and M. spinicercata, of which males are known) by the shape of last tergite and cerci.

Etymology. This species is named after Alain Pauly (Directorate Taxonomy and Phylogeny, Royal Belgian Institute of Natural Sciences, Bruxelles), who collected many interesting Orthoptera in Gabon and Madagascar, now preserved at the RBINS.

\section{Angustithorax spiniger Massa, 2015 \\ Figs 16A-16C}

Massa, 2015. Zookeys, 472: 91.

Material examined. Democratic Republic of Congo, Lulkaburg (=Kananga) IV-V.1967 (1 ${ }^{\Uparrow}$ ); Democratic

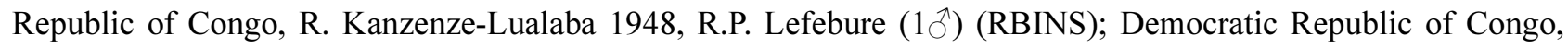
Lubumbashi 3.II.1968 (ô holotype), T. De Stefani (MRT). 

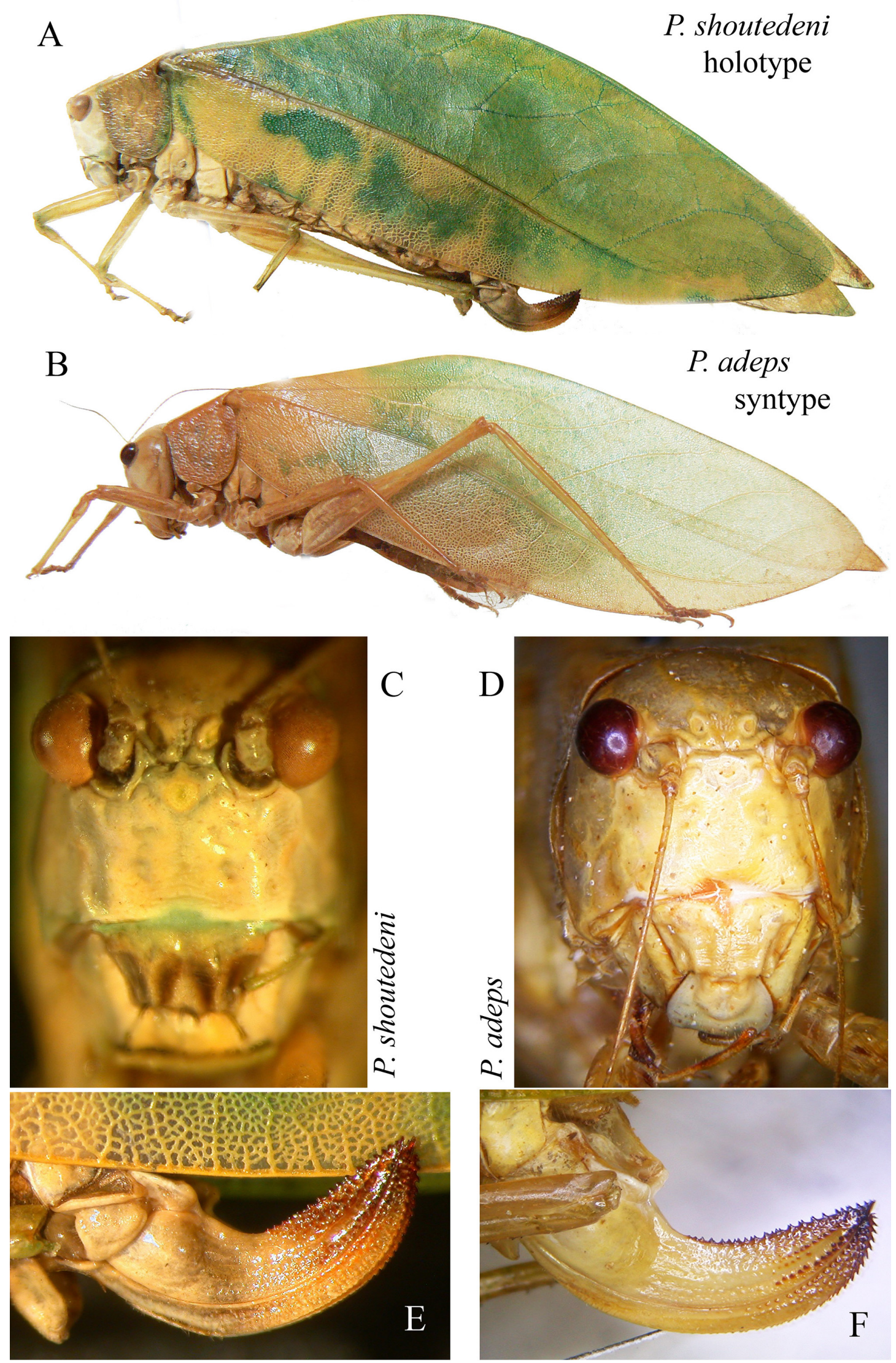

FIGURE 14. A) Plangiopsis shoutedeni Griffini, 1908 female holotype in lateral view. B) Plangiopsis adeps Karsch, 1896 female syntype in lateral view. C) Face of $P$. shoutedeni female holotype in frontal view. D) Face of $P$. adeps in frontal view. E) Female ovipositor of $P$. shoutedeni holotype in lateral view. F) Female ovipositor of $P$. adeps in lateral view. 


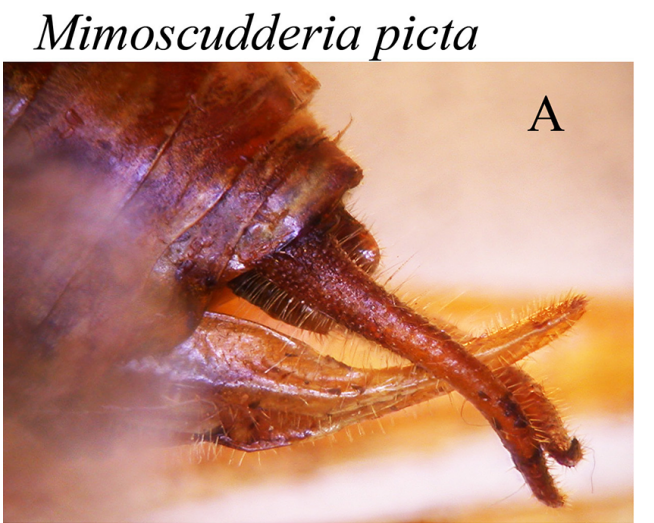

Mimoscudderia paulyi $\mathrm{n}$. sp.
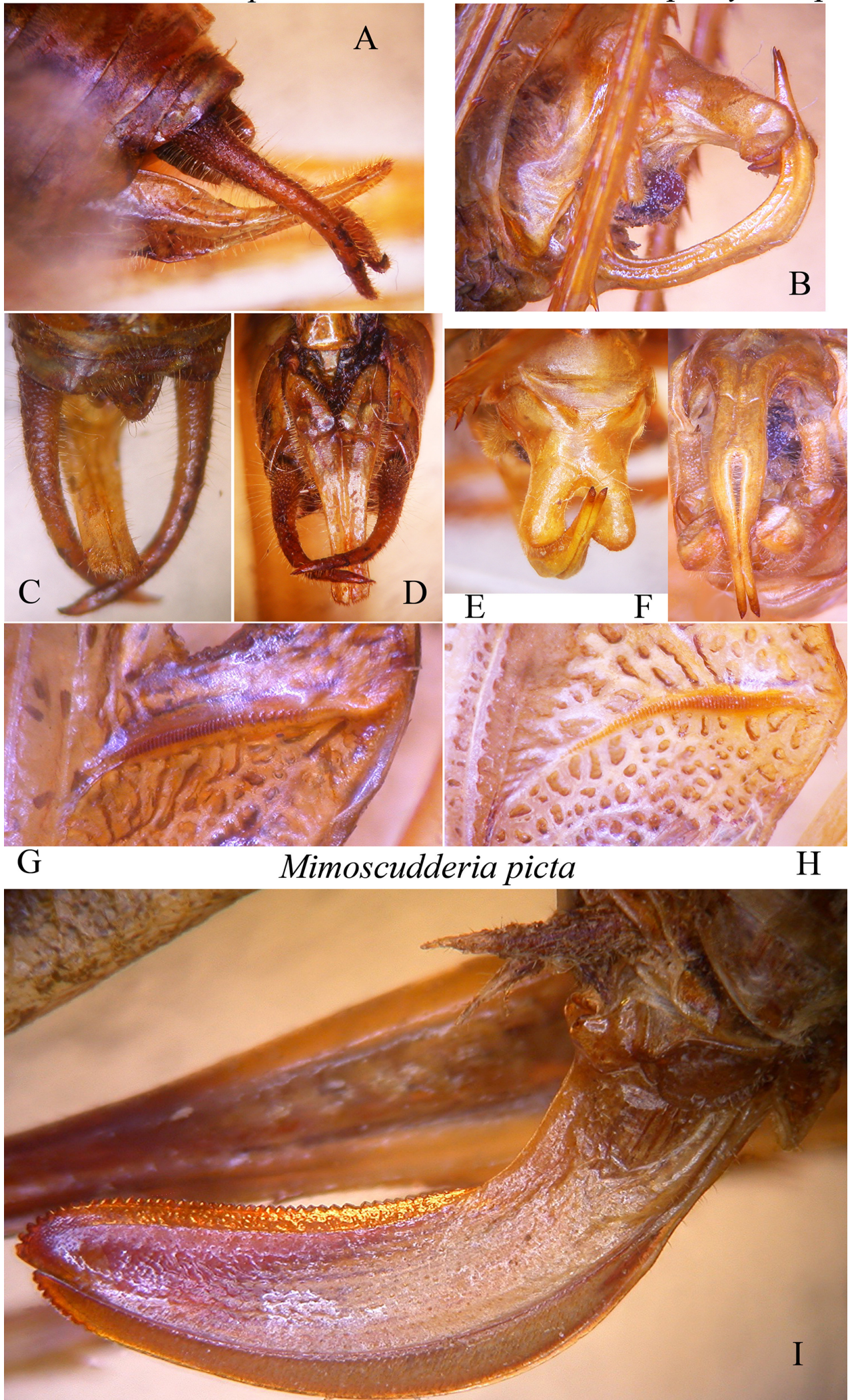

FIGURE 15. Two Madagascar species of the genus Mimoscudderia. A) Lateral view of last abdominal segments of Mimoscudderia picta Carl, 1914. B) Lateral view of last abdominal segments of Mimoscudderia paulyi n. sp. holotype. C) Dorsal view of male cerci and subgenital plate of $M$. picta. D) Ventral view of male cerci and subgenital plate of $M$. picta. E) Dorsal view of male processus and subgenital plate of $M$. paulyi n. sp. F) Ventral view of male processus and subgenital plate of $M$. paulyi n. sp. G) Stridulatory file of left tegmen of M. picta. H) Stridulatory file of left tegmen of M. paulyi n. sp. I) Lateral view of the ovipositor of M. picta. 

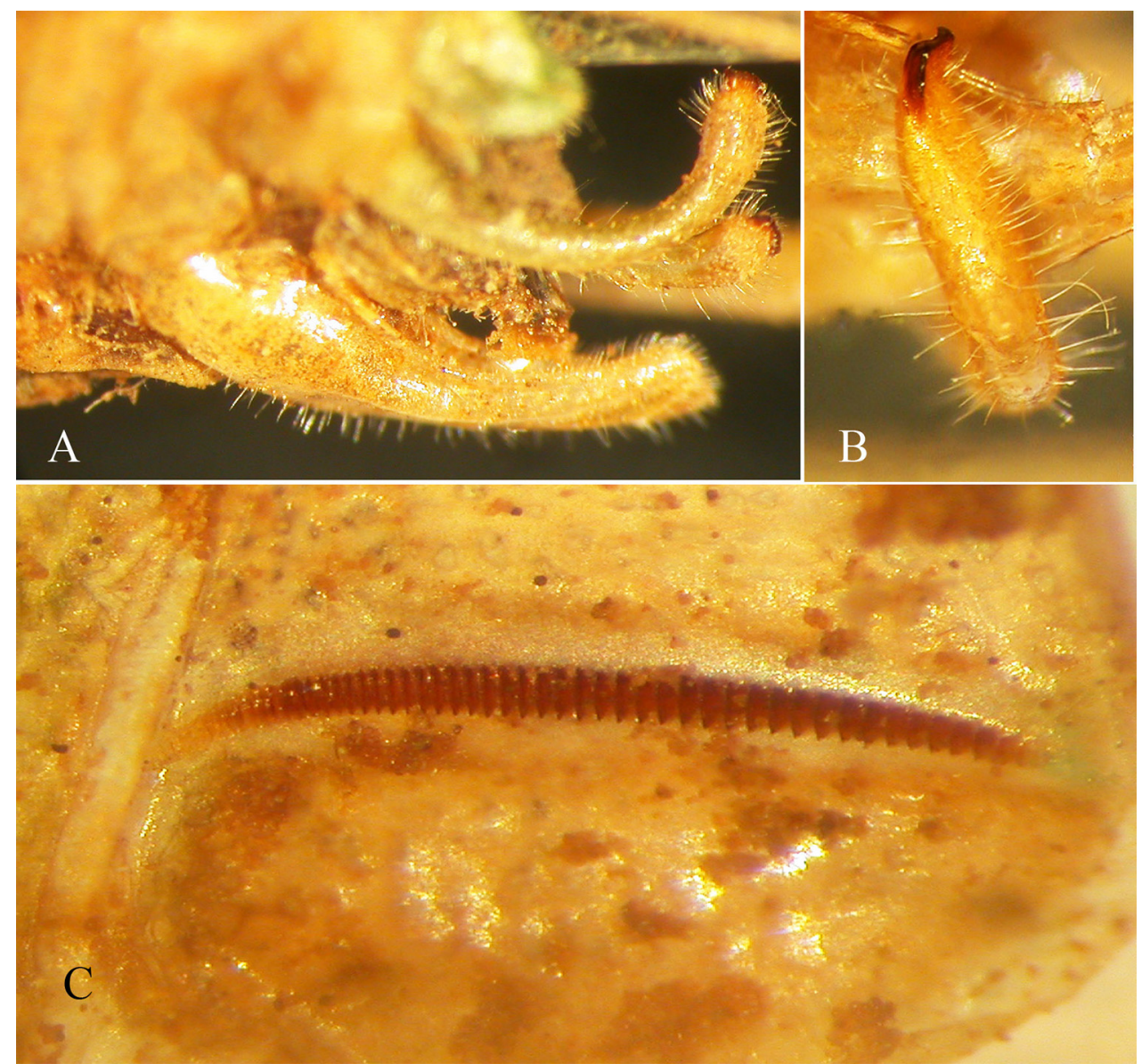

FIGURE 16. Angustithorax spiniger Massa, 2015 male. A) Lateral view of last abdominal segments. B) Apex of the left cercus. C) Stridulatory file of left tegmen.

Measurements. Body length: 21.3-22.0; length of pronotum: 6.4-6.8; height of pronotum: 4.6-4.8; width of the pronotum: 1.5-2.0; length hind femur: 17.2-19.5; length of hind tibia: 18.3-21.5; length of tegmina: 31.1-37.3; width of tegmina: $7.6-8.1$.

Remarks. This species is only known from the holotype, a male collected at Lubumbashi (Democratic Republic of Congo), and currently is the sole representative of the genus (Massa 2015). The two specimens listed above concur well with the description of this peculiar taxon, including its very narrow anterior part of the pronotum (see measurements), after which the Latin name of the genus.

Concerning the position of cerci, in the holotype are reported below the subgenital plate, but supposedly artificial in the mounted specimen. Actually the insect holds the cerci otherwise, above the subgenital plate. Cerci are very distinctive: their tip is black and chitinous, with the shape of a small spoon (Figs 16A, 16B). The stridulatory file, still not described, is $1.6 \mathrm{~mm}$ long, nearly straight, and consists of ca. 45 evenly spaced teeth (Fig. 16C).

\section{Pseudogoetia n. gen.}

Figs 17A-17E

Species type of the genus: Pseudogoetia constanti $\mathbf{n}$. sp., here designated.

Description. Large size, short head, wide round eyes, fastigium verticis short, of the same size of the scapus of antennae, prozona hardly narrower than metazona of pronotum; anterior margin of pronotum slightly rounded, posterior margin rounded, with evident lateral excisions. Tegmina wider than pronotum length, with the apical margins obliquely cut; hind wings longer than tegmina. Fore coxae armed. Dorsal margin of fore tibiae round (not furrowed). Tympanum of fore tibiae open on inner and on outer side. Fore femora with spines on ventral margins, 
ventral margins of hind femora armed. Hind tibiae furrowed, longer than the femora. Lower margin of hind genicular lobe bearing an accessory spine. Meso and metasternum rounded. Supra-anal plate of the male triangular and rounded, male cerci in-curved. Subgenital plate of the male narrow, three-keeled, with the posterior margin concave and with styli.
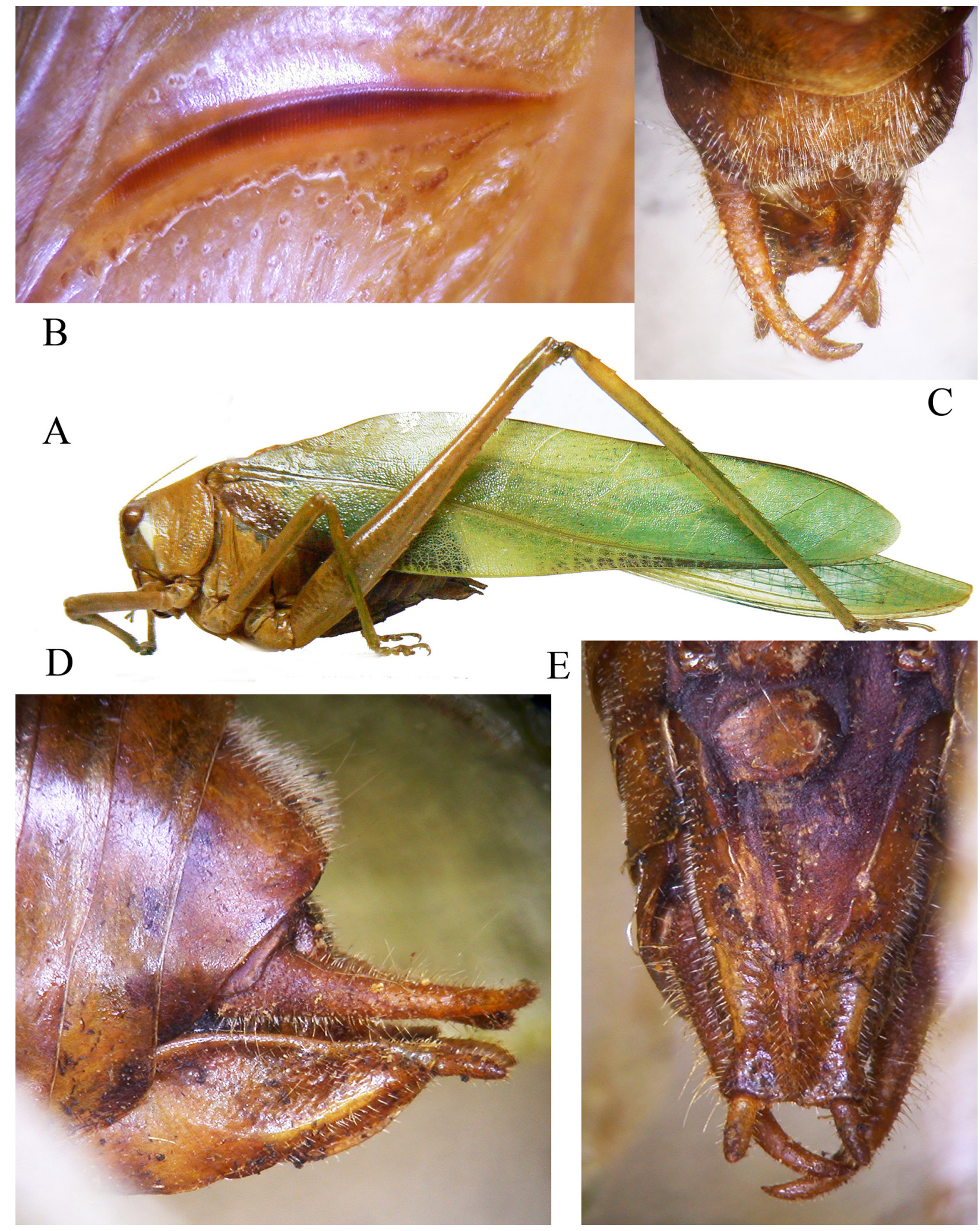

FIGURE 17. Pseudogoetia constanti n. gen. n. sp. A) Lateral view of the male holotype. B) Stridulatory file of left tegmen. C) Dorsal view of male last abdominal segments and cerci. D) Lateral view of male last abdominal segments and cerci. E) Ventral view of the male subgenital plate. 
Remarks. This genus is vaguely similar to Goetia Karsch, 1891; differences are mainly on the shape of the fastigium of vertex, pronotum, and the open inner tympanum on fore tibiae. It is not easy to place Pseudogoetia into a tribe. In Table 1 there are listed the main characters of 5 genera, including this one. It should very probably belong to Phaneropterini, but one character (upper margin of fore tibia not furrowed) is not shared with other genera of this tribe, while it is found in the newly described Madagascar genus Madagascarantia (Massa 2017a). It is interesting to highlight that this is a rare character, found mainly in the Madagascar genera.

Etymology. Pseudo = false, Goetia $=$ genus of Phaneropterinae.

TABLE 1. Differences among some genera of large Phaneropterinae probably related between them (after Massa 2017a, modified)

\begin{tabular}{|c|c|c|c|c|c|}
\hline Character & $\begin{array}{l}\text { Madagascarantia } \\
\text { (tribe Phaneropterini?) }\end{array}$ & $\begin{array}{l}\text { Arantia/Euarantia } \\
\text { (tribe Arantiini) }\end{array}$ & $\begin{array}{l}\text { Pseudogoetia } \\
\text { (tribe Phaneropterini?) }\end{array}$ & $\begin{array}{l}\text { Goetia } \\
\text { (tribe Arantiini) }\end{array}$ & $\begin{array}{l}\text { Holochlora } \\
\text { (tribe Holochlorini) }\end{array}$ \\
\hline $\begin{array}{l}\text { Fastigium of } \\
\text { vertex }\end{array}$ & wider than scapus & as large as scapus & as large as scapus & as large as scapus & as large as scapus \\
\hline $\begin{array}{l}\text { Compound } \\
\text { eyes }\end{array}$ & round & round & round & round & semi-spherical \\
\hline $\begin{array}{l}\text { Spine fore } \\
\text { coxae }\end{array}$ & yes & no & yes & yes & yes \\
\hline $\begin{array}{l}\text { Dorsal } \\
\text { margin fore } \\
\text { tibia }\end{array}$ & round (not furrowed) & furrowed & round (not furrowed) & furrowed & furrowed \\
\hline $\begin{array}{l}\text { Inner } \\
\text { tympanum }\end{array}$ & open & closed & open & closed & closed \\
\hline $\begin{array}{l}\text { Outer } \\
\text { tympanum }\end{array}$ & open & open or closed & open & open & open \\
\hline $\begin{array}{l}\text { Stridulatory } \\
\text { vein of left } \\
\text { tegmen }\end{array}$ & normal & normal & $\begin{array}{l}\text { elevated above wing } \\
\text { plane }\end{array}$ & $\begin{array}{l}\text { normal or } \\
\text { elevated above } \\
\text { wing plane }\end{array}$ & $\begin{array}{l}\text { elevated above wing } \\
\text { plane or normal }\end{array}$ \\
\hline $\begin{array}{l}\text { Stridulatory } \\
\text { file }\end{array}$ & normal & normal & normal & normal & bulging in middle \\
\hline Last tergite & not modified & not modified & not modified & not modified & modified \\
\hline Ovipositor & $\begin{array}{l}\text { robust, wide, apically } \\
\text { rounded }\end{array}$ & $\begin{array}{l}\text { small, reduced, } \\
\text { valves of different } \\
\text { length }\end{array}$ & unknown & $\begin{array}{l}\text { small, reduced, } \\
\text { valves of } \\
\text { different length }\end{array}$ & $\begin{array}{l}\text { robust, wide, } \\
\text { apically tipped }\end{array}$ \\
\hline
\end{tabular}

\section{Pseudogoetia constanti n. sp.}

Figs 17A-17E

Material examined and depository. Democratic Republic of Congo, Elisabethville (now Lubumbashi) 27.IV.1939, H.J. Brédo (light) ( ${ }^{\Uparrow}$ holotype, 10 paratype, without hind legs) (RBINS).

Measurements. Body length: 30.8-31.4; length of pronotum: 8.5-9.1; height of pronotum: 8.8-9.1; length hind femur: 33.0; length of hind tibia: 35.6; length of tegmina: 55.9-60.3; width of tegmina: 13.9-14.0.

Diagnosis. This is a large Phaneropterinae vaguely similar to a Goetia, but has open tympana on inner side of fore tibiae, a whitish stripe beyond the eye, the stridulatory vein of left tegmen elevated above wing plane, dorsal margin of fore tibiae round (not furrowed), fore coxae armed.

Description of male. Colour. Brown with green tegmina, one brown stripe on the anterior margin of tegmina, one evident white stripe beyond the eyes (Fig. 17A). Short head, wide round eyes, fastigium verticis short, of the same size of the scapus of antennae, sulcate. Prozona of pronotum slightly narrower than metazona; anterior margin of pronotum hardly rounded, posterior margin rounded, with evident lateral excisions; pronotum longer than high, integuments rough. Lower margin of lateral lobes of pronotum undulate. Tegmina wider than pronotum length, leathery, with the apical margins obliquely cut; hind wings longer than tegmina. Stridulatory vein of left 
tegmen elevated above wing plane. Stridulatory file, $1.6 \mathrm{~mm}$ long, with more than 100 evenly spaced and elevated teeth (Fig. 17B). Dorsal margin of fore tibiae round (not furrowed). Fore coxae armed. Ventral margins of fore tibiae with 3-4 small spines; tympanum of fore tibiae open on inner and on outer side. Mid tibia with 5-6 spines ventrally on outer and 2-3 on inner margin; dorsal inner margin with 3 spines. Ventral margins of femora furrowed, fore femora with 3-4 spines on inner ventral margin, mid femora with 2 small spines on outer ventral margin, hind femora armed ventrally with 11-12 brown black tipped spines on outer and 7-8 on inner margins. Hind tibiae furrowed, longer than the femora. Lower margin of hind genicular lobe bearing an accessory spine. Meso and metasternum rounded. Supra-anal plate of the male triangular and rounded, male cerci long, in-curved and pointed (Figs 17C, 17D, 17E). Subgenital plate narrow, stout, three-keeled, its posterior margin concave, with stout and flat styli (Figs 17D, 17E).

Etymology. This species is named after Jerome Constant (Directorate Taxonomy and Phylogeny RBINS), who facilitated the study of the Orthoptera material within a Synthesys project carried out by the author at RBINS.

Remarks. Table 1 shows the affinities among some genera of large Phaneropterinae living in tropical Africa and Madagascar. Pseudogoetia has in common with Madagascarantia Massa 2017 the dorsal margin of fore tibiae not furrowed and open tympana on inner side of fore tibiae; in addition, it has in common with Goetia purpurea Massa, 2013 and most Holochlora Stål, 1873 the stridulatory vein of left tegmen elevated above wing plane. This ensemble of characters does not allow to understand the actual affinities with the other genera and the tribe to which it may belong.

\section{Materuana abyssinica n. sp.}

Figs $18 \mathrm{~A}-18 \mathrm{E}$

Material examined and depository. Abyssinie (Ethiopia), Maraco (= Marracò) ( $\widehat{o}$ holotype) (RBINS). Other material examined. Materuana eriki Hemp, 2017. Tanzania, East Usambara Mountains, Sigi Nature Trail II.2017, C. Hemp $\left(1 \jmath^{\lambda}, 1\right.$ 우) (BMCP).

Among the unidentified specimens preserved at the Royal Belgian Institute of Natural Sciences, Bruxelles one old specimen collected in Ethiopia has been found; it is here being placed as a new species, tentatively belonging to the genus Materuana Hemp, 2017.

Measurements. Body length: 31.9; length of pronotum: 8.1; height of pronotum: 9.0; length hind femur: 20.0; length of tegmina: 46.0 ; width of tegmina: 16.5 .

Diagnosis. Main differences between this new species and the only previously known species, Materuana eriki Hemp, 2017 are: eyes not protruding, fore coxae and fore femora unarmed (Hemp 2017).

Description. Male. Habitus and colour. Fully winged, medium sized, yellowish-green with red eyes, posterior margin of pronotum blackish, tegmina with blackish posterior margin. Eyes oval, not protruding. Fastigium of vertex laterally compressed, produced between scapi of antennae, above slightly sulcate, separated from fastigium of frons by a sulcus (Figs 18A, 18B). Antennae lacking in the specimen. Pronotum rounded, pronotal lobes higher than long, humeral sinus deep. Anterior margin of pronotum straight, posterior margin rounded. Fore coxae, fore femora and mid femora unarmed, hind femora with 4 small spines on inner and 2 on outer ventral margins. Fore tibiae with closed tympanum on inner side and open on outer one. Fore tibiae with 2 spines on ventral margins +1 spur on each side, mid tibiae with 3 spines on ventral margins +1 spur on each side, hind tibiae with 6 spines on outer ventral margin and 2 on inner ventral margin, 20 spines on both dorsal margins +3 spurs on each side. Tegmina 2.8 times as long as wide, with rounded apex, opaque and shiny, with main veins slightly elevated above wing plane. Second pairs of wings as long as tegmina. Stridulatory file curved and long, consisting of ca. 70 small evenly spaced teeth (Fig. 18C). Last abdominal tergite undifferentiated, cerci thin, incurved with pointed tips. Subgenital plate basally broad, triangular, ending with a small concavity, styli short (Figs 18D, 18E).

Etymology. After the Ethiopia's old Latin name, Abyssinia; abyssinica is adjective feminine.

Distribution. Known only from the type locality (Marracò), which is in the Oromia region, about $100 \mathrm{~km}$ South of Addis Abeba, between Zuai Lake and Tufa marshes (R. Poggi, pers. comm.). 


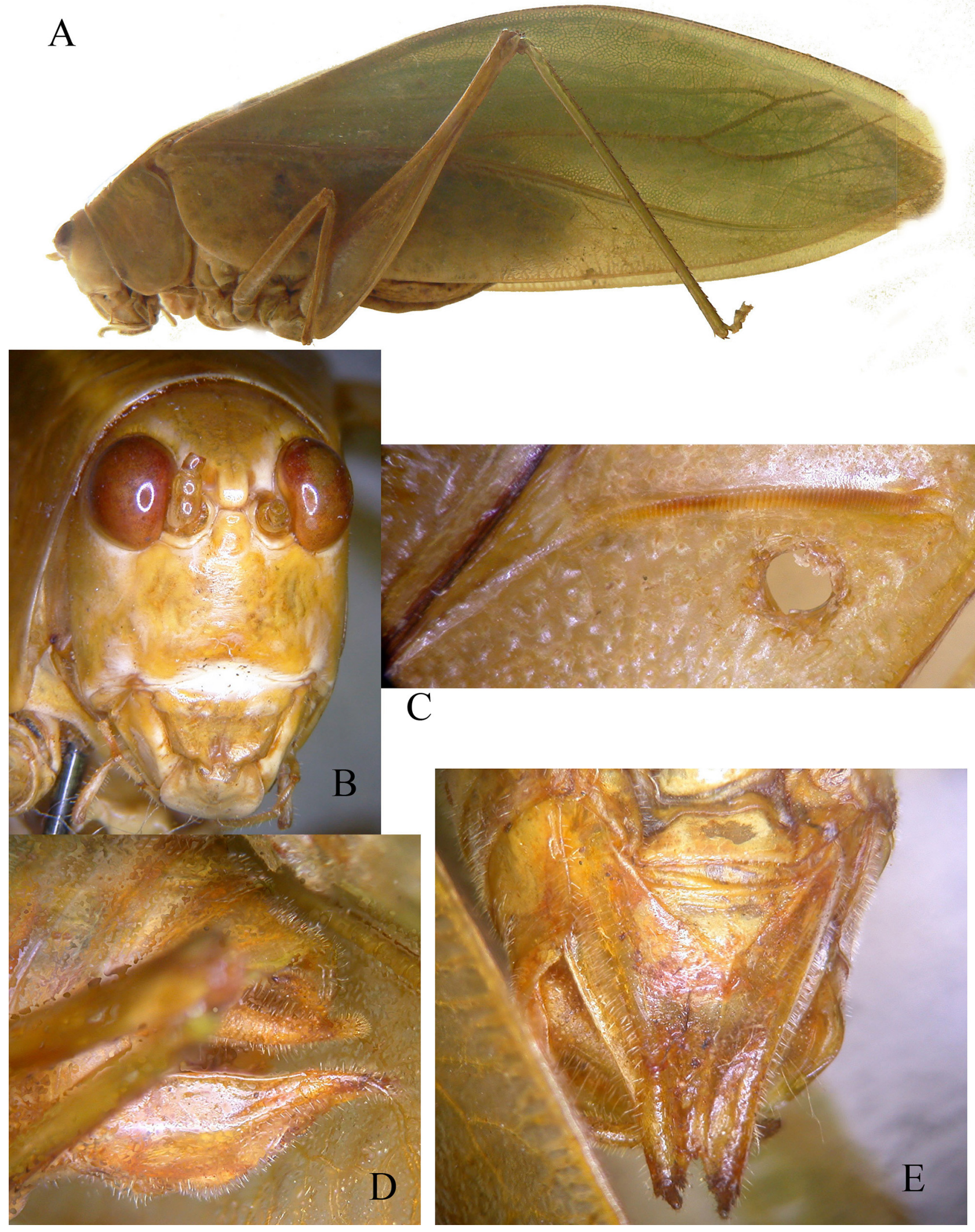

FIGURE 18. Materuana abyssinica n. sp. holotype A) Lateral view. B) Face in frontal view. C) Stridulatory file of the left tegmen. D) Lateral view of the last abdominal segments. E) Ventral view of the subgenital plate. 


\section{Acknowledgements}

This research received support from the Synthesys Project, which is financed by European Community Research Infrastructure Action under the FP7 "Capacities" Programme at the Royal Belgian Institute of Natural Sciences, Bruxelles (2017: BE-TAF-6319). Many useful data were obtained during previous similar activities at the Museo Nacional de Ciencias Naturales, Madrid (CSIC) (2013: ES-TAF-2438), the Museum für Naturkunde, Berlin (2014: DE-TAF-4109), the Naturhistorisches Museum, Vienna (2016: AT-TAF-5324) and the National Museum of Natural History, Prague (2016: CZ-TAF-5559). I am especially indebted to Jerome Constant (Royal Belgian Institute of Natural Sciences, Bruxelles) for his assistance and for the loan of some specimens, Martin Fikáček (National Museum Natural History, Prague), Suzanne Randolf and Harald Bruckner (Naturhistorisches Museum, Vienna), Mercedes Paris (Museo Nacional de Ciencias Naturales, Madrid), Michael Ohl (Museum für Naturkunde, Berlin), Roberto Poggi, Maria Luisa Tavano and Giuliano Doria (Museo Civico di Storia Naturale 'G. Doria', Genoa), who all facilitated the study of specimens preserved in their museums. I thank also Carole Paleco (RBINS) for her assistance during my stay at Museum of Bruxelles. I am also very much indebted to Philippe Moretto, who kindly made available to study the material collected during 2012-2017 in central and west African countries. I also thank very much Claudia Hemp, for her advices about the possible identification of Materuana and for specimens of Materuana eriki sent for comparison, and John J. Borg for checking English language.

\section{References}

Brunner von Wattenwyl, C. (1878) Monographie der Phaneropteriden. Vienna, 401 pp. pteridae pars 2a (reliquae species omnes). Mémoires de la Societé entomologique Belgique, 15, 201-226. Available from: http:// www.biodiversitylibrary.org/item/37136 (Accessed 20 Nov. 2017)

Cadeña-Castaneda, O. (2015) Suprageneric taxa derived from Amblycoryphini sensu lato (Orthoptera: Tettigonioidea: Phaneropteridae: Phaneropterinae). Zootaxa 3904 (3), 409-414. https://doi.org/10.11646/zootaxa.3904.3.6

Carl, J. (1914) Orthoptères de Madagascar (Phaneropterides et Pseudophyllides). Revue Suisse de Zoologie 22 (6), $147-177$. https://doi.org/10.5962/bhl.part.82532

Chopard, L. (1958) Les Orthopteroides des Comores. Mémoires de l'Institut Scientifique de Madagascar, Série Entomologie $10,3-40$.

Enderlein, G. (1907) Pardalota karschiana, eine neue ost-afrikanische Orthoptere. Zoologische Jahrbücher. Abteilung für Systematik, Geographie und Biologie der Tiere 25, 197-200.

Giglio-Tos, E. (1907) Ortotteri Africani. Parte II. Blattodea, Mantodea, Phasmodea, Locustodea, Gryllodea. Bollettino dei Musei di Zoologia ed Anatomia Comparata della R. Università di Torino, 22 (563), 1-26. Available from: http:// www.biodiversitylibrary.org/item/43468\#page/125/mode/1up (Accessed 20 Nov. 2017)

Griffini, A. (1906) Ortotteri raccolti da Leonardo Fea nell'Africa occidentale. 1. Hetrodidi, Conocephalidi, Meconemidi, Pseudophyllidi, Mecopodidi e Fanerotteridi. Annali del Museo Civico di Storia Naturale di Genova, 3 (2), 358 -397.

Griffini, A. (1908) Phasgonuridae africane del R. Museo di Storia Naturale in Bruxelles. 6. Phaneropteridae pars 2a (reliquae species omnes). Mémoires de la Societé entomologique Belgique, 15, 201-226. Available from: pteridae pars 2a (reliquae species omnes). Mémoires de la Societé entomologique Belgique, 15, 201-226. Available from: http:// www.biodiversitylibrary.org/item/41740\#page/215/mode/1up (Accessed 1 Nov. 2017)

Hadley, A. (2008) Combine Z. Available from: www.hadleyweb.pwp.blueyonder.co.uk (Accessed 1 Feb. 2009)

Heller, K.G., Hemp, C., Liu, C. \& Volleth, M. (2014) Taxonomic, bioacoustics and faunistic data on a collection of Tettigonioidea from Eastern Congo (Insecta: Orthoptera). Zootaxa, 3785 (3), 343-376. https://doi.org/10.11646/zootaxa.3785.3.2

Hemp, C. (2017) Annotated checklist of Orthoptera from Kazimzumbwi Forest Reserve, Tanzania with the description of new species and discussion of the biogeographic patterns of threatened species. Zootaxa 4226 (2), 151-193. https://doi.org/10.11646/zootaxa.4226.2.1

Karsch, F. (1887) Zwei neue ostafrikanische Phaneropteriden. Entomologische Nachrichten, 13, 52-54. pteridae pars 2a (reliquae species omnes). Mémoires de la Societé entomologique Belgique, 15, 201-226. Available from: http:// www.biodiversitylibrary.org/item/100978\#page/78/mode/1up (Accessed 20 Nov. 2017)

Karsch, F. (1889) Orthopterologische Beiträge III. Berliner Entomologische Zeitschrift, 32 (1888), 415-464.pteridae pars 2a (reliquae species omnes). Mémoires de la Societé entomologique Belgique, 15, 201-226. Available from: http:// www.biodiversitylibrary.org/item/34458\#page/475/mode/1 up (Accessed 20 Nov. 2017)

Karsch, F. (1890) Verzeichnis der von Herrn Dr. Paul Preuss auf der Barombi-Station in Deutsch-Westafrika 1890 gesammelten Locustodeen aus den Familien der Phaneropteriden, Mekonemiden und Gryllakriden. Entomologische Nachrichten 16 (23), 353-369. pteridae pars 2a (reliquae species omnes). Mémoires de la Societé entomologique Belgique, 15, $201-226$. 
Available from: http://www.biodiversitylibrary.org/item/81935\#page/367/mode/1up (Accessed 20 Nov. 2017)

Karsch, F. (1891) Verzeichnis der von Herrn Dr. Paul Preuss in Kamerun erbeuteten Acridiodeen. Berliner Entomologische Zeitschrift, 36 (1), 175-196.

https://doi.org/10.1002/mmnd.18910360116

Karsch, F. (1896) Neue Orthopteren aus dem tropischen Afrika. Stettiner Entomologische Zeitung 57, 242-359.pteridae pars 2a (reliquae species omnes). Mémoires de la Societé entomologique Belgique, 15, 201-226. Available from: http:// www.biodiversitylibrary.org/item/36013\#page/250/mode/1 up (Accessed 20 Nov. 2017)

Massa, B. (2013) Diversity of leaf katydids (Orthoptera: Tettigoniidae: Phaneropterinae) of Dzanga-Ndoki National Park, Central African Republic, with selected records from other African countries. Journal of Orthoptera Research 22, 125152. https://doi.org/10.1665/034.022.0201

Massa, B. (2015) New genera, species and records of Phaneropterinae (Orthoptera, Phaneropteridae) from sub-Saharan Africa. Zookeys 472, 77-102. https://doi.org/10.3897/zookeys.472.8575

Massa, B. (2016) On some interesting African katydids (Orthoptera Tettigoniidae). Entomologia 4 (303), 1-15. https://doi.org/10.4081/entomologia.2016.303

Massa, B. (2017a) New taxa of Orthoptera (Insecta Tettigoniidae Phaneropterinae) from Madagascar. Zootaxa, 4242 (2), 299 312. https://doi.org/10.11646/zootaxa.4242.2.5

Massa, B. (2017b) New data and taxa for Orthoptera Tettigoniidae and Acrididae from tropical Africa. Annales Société Entomologique de France 53, 236-255. https://doi.org/10.1080/00379271.2017.1334586

Ragge, D.R. (1980) A review of the African Phaneropterinae with open tympana (Orthoptera: Tettigoniidae). Bulletin British Museum (Natural History) Entomology 40, 1-192. pteridae pars 2a (reliquae species omnes). Mémoires de la Societé entomologique Belgique, 15, 201-226. Available from: http://www.archive.org/details/bulletinofbritis40entolond (Accessed 29 Nov. 2017)

Sjöstedt, Y. (1912) Zur Orthopterenfauna des Kamerungebirges. Arkiv för Zoologi 7 (37), 1-30. [pl. 1-3.]pteridae pars 2a (reliquae species omnes). Mémoires de la Societé entomologique Belgique, 15, 201-226. Available from: http:// www.biodiversitylibrary.org/item/30233\#page/857/mode/1 up (Accessed 20 Nov. 2017)

Stål, C. (1874) Recencio Orthopterorum. Révue critique des Orthoptères décrits par Linné, De Geer et Thunberg. 2 Locustina, $121 \mathrm{pp}$.

Stål, C. (1876) Bidrag till södra Afrikas Orthopter-fauna. Öfversigt af Kongliga Vetenskaps-Akademiens Förhandlinger 33 (3), 29-76. pteridae pars 2a (reliquae species omnes). Mémoires de la Societé entomologique Belgique, 15, 201-226. Available from: http://www.biodiversitylibrary.org/item/100513\#page/177/mode/1up (Accessed 20 Nov. 2017) 